\title{
Working
}

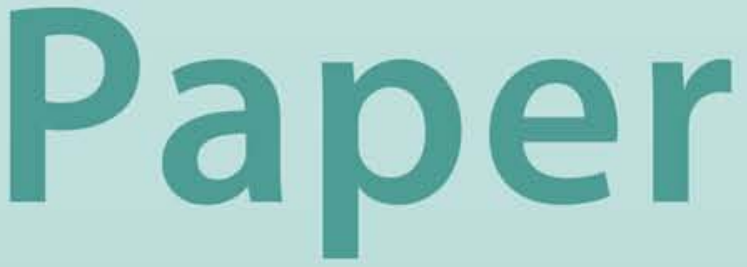




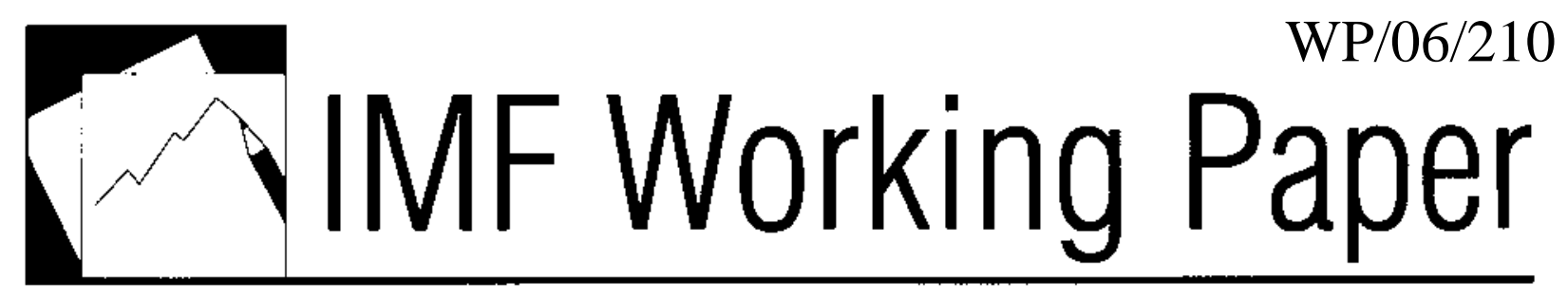

Growth and Reforms in Latin America: A Survey of Facts and Arguments

Jeromin Zettelmeyer 


\title{
IMF Working Paper
}

Western Hemisphere Department

\section{Growth and Reforms in Latin America: A Survey of Facts and Arguments ${ }^{1}$}

\author{
Prepared by Jeromin Zettelmeyer
}

Authorized for distribution by Caroline Atkinson

September 2006

\begin{abstract}
This Working Paper should not be reported as representing the views of the IMF.

The views expressed in this Working Paper are those of the author(s) and do not necessarily represent those of the IMF or IMF policy. Working Papers describe research in progress by the author(s) and are published to elicit comments and to further debate.

This paper presents a number of facts about growth in Latin America, and shows how critical correlates of growth have evolved over time. In comparison with other regions, Latin America has consistently exhibited higher macroeconomic volatility, lower openness, and higher income inequality, though openness and macroeconomic stability have improved since the early 1990s. The paper then discusses three views of why reforms have not led to higher growth in Latin America: that reforms have gone too far; that reforms have not gone far enough; and that reforms have missed the point.

JEL Classification Numbers:O11, O15, O17, O54

Keywords: Growth, Reforms, Volatility, Latin America

Author’s E-Mail Address: JZettelmeyer@imf.org

\footnotetext{
${ }^{1}$ This paper was originally written as background for a conference on Latin America held at the IMF in May 2006. I am very grateful to Caroline Atkinson, Mauricio Cárdenas, Ben Clements, Charles Collyns, Javier Corrales, Simon Johnson, Eduardo Lora, Guillermo Perry, Ratna Sahay, Anoop Singh, Mariano Tommasi, Chris Towe, and participants at the conference and at the IMF's Western Hemisphere Department seminar for comments, and to Torbjörn Becker and Paolo Mauro for sharing their data on output drops and shocks. I am also grateful to Andy Berg, Jonathan Ostry, and Carlos Leite for discussions and some joint work that this paper draws on.
} 


\section{Contents}

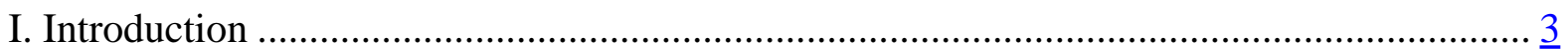

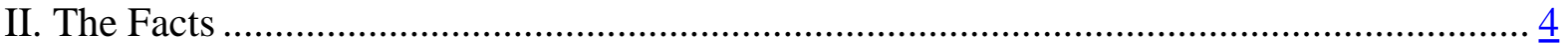

A. Growth Patterns in Latin America: Six Facts and a Conjecture ….................................... 4

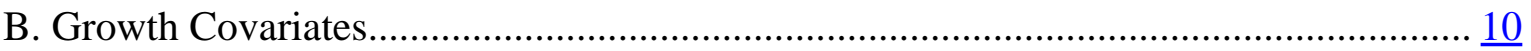

III. The Arguments: Why Did Reforms Not Lead to Higher Growth?.................................... 17

A. "Reforms Did Not Go Far Enough"......................................................................... 18

Industry-Level Evidence...................................................................................... 18

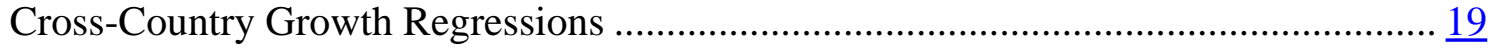

B. "Reforms Have Gone Too Far"............................................................................... 22

C. "Reforms Have Missed the Point" .............................................................................. 24

Fundamental Constraints to Growth ...................................................................... 25

Binding Constraints at the Country Level ..................................................................... 28

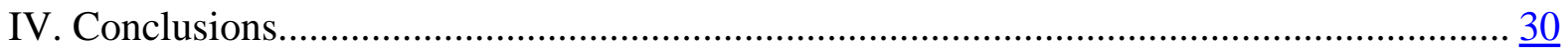

References................................................................................................................

Table

1. Frequency and Duration of Growth Spells ................................................................. $\underline{9}$

Figures

1. Latin America: Real GDP Growth, 1970-2005 ……….............................................

2. Latin America: Relative Income and Structural Reforms..............................................

3. Developing Country Regions: GDP Per Capita Growth, 1970-2005 …….....................

4. Latin America: Growth Accounting by Decade, 1960-2000 ………………...............

5. Latin American Countries: Income Per Capita...............................................................

6. Frequency of Large Output Drops, by Region..............................................................

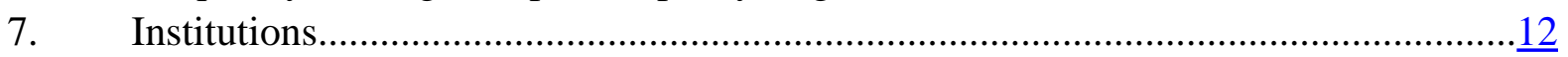

8. Social Indicators............................................................................................

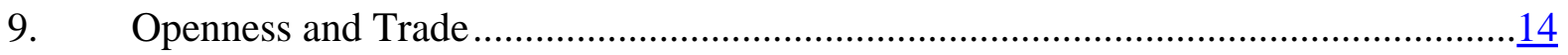

10. Macroeconomic and Public Expenditure Policies ..................................................... 15

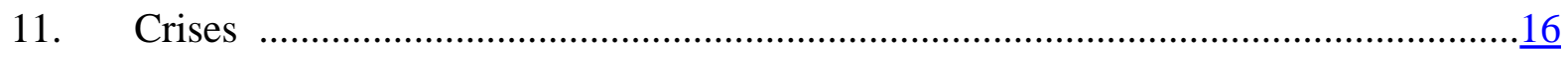

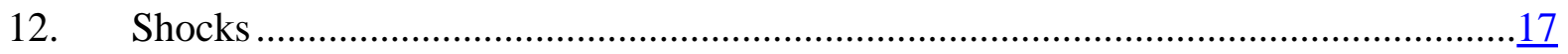




\section{INTRODUCTION}

These are hopeful times for Latin America. The region has overcome its most recent bout of economic crisis. Just like its predecessors, the latest crisis involved currency collapses, sovereign defaults, output declines, and a surge in unemployment and poverty. Unlike its predecessors in the 1930s and 1980s, however, the crisis led neither to coups or reversals to dictatorship, nor to high inflation. Several countries-including Argentina, Bolivia, Ecuador, Haiti, Peru, and Venezuela—suffered periods of political instability, but in most cases these were overcome without large-scale

Figure 1. Latin America: Real GDP Growth, 1970-2005

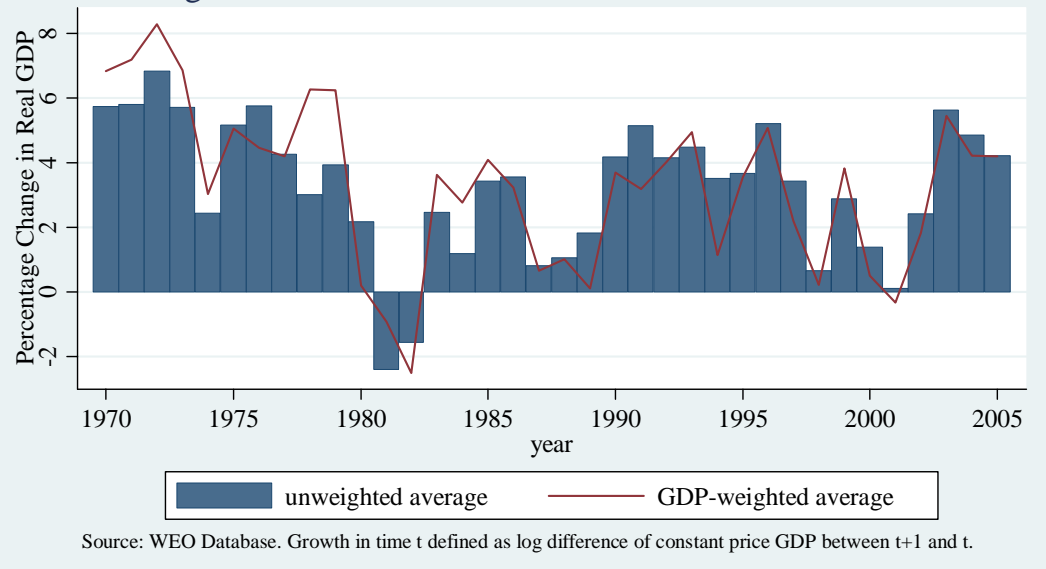
violence or interruptions

of the constitutional order. Last but not least, countries that suffered sharp output losses have witnessed V-shaped recoveries, and are by now exceeding their pre-crisis output levels. If output evolves in line with projections for 2006, the recent recovery will have been Latin America’s fastest three-year period of growth since the mid-1970s (Figure 1).

In spite of these successes, however, there is dissatisfaction with the outcome of market reforms in many countries in the region. Some of this is because economic growth has not always reached those who need it most: although social indicators have significantly improved, income poverty has come down more slowly, and income inequality has increased in some countries.

However, there is also dissatisfaction with the pace of growth itself, given benchmarks outside the region and, perhaps, initial expectations. Figure 2 shows one sense in which growth in the region has indeed been disappointing: it has failed to narrow the income gap relative to the highincome countries (defined here as countries with

Figure 2. Latin America: Relative Income and Structural Reforms

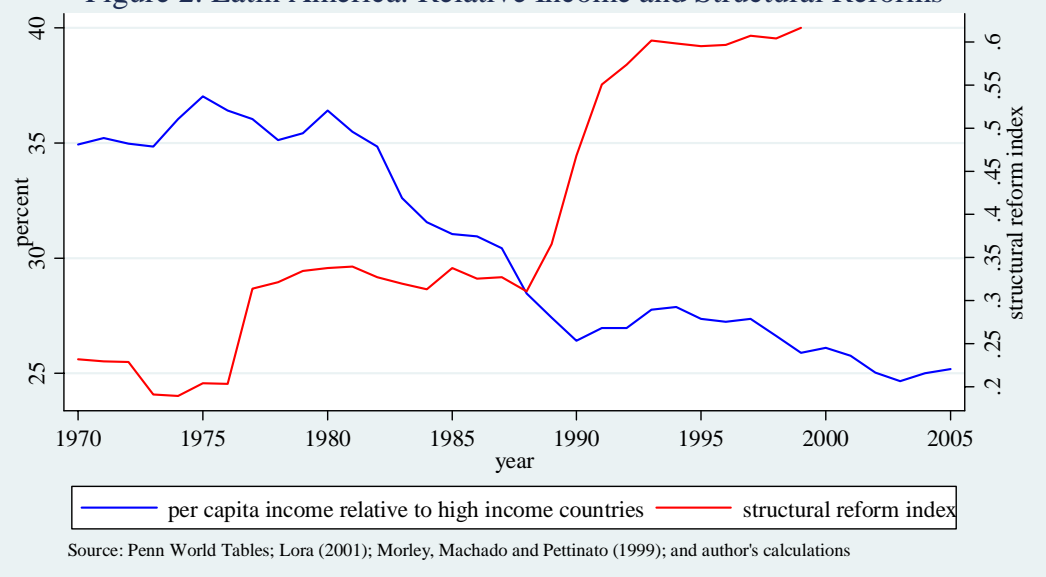


levels of per capita income higher than Latin America’s richest country in 1970). ${ }^{2}$ This has occurred in spite of significant structural reforms, particularly in the late 1980s and early 1990s. To be sure, most of the widening of the income gap occurred in the 1980s, before the big reforms, and the gap did in fact narrow between 1990 and the 1998 "sudden stop" in capital flows to emerging markets. Furthermore, a few countries such as Chile and the Dominican Republic grew faster and narrowed their gaps over the period as a whole. For the region as whole, however-as well as most individual countries-income fell behind both between 1980 and 2005 and 1990 and 2005.

The purpose of this paper is to provide background to those who are grappling with the question of why Latin America has not enjoyed higher growth, in spite of its reform efforts. It does so both by providing essential facts and by surveying the recent literature on reforms and growth in Latin America. Section II.A provides facts on output and growth patterns in the region, both over time and compared with other regions. Section II.B does the same for a number of economic, social, and political variables that are usually viewed as related to growth (though with causality generally running in both directions). We then lay out the basic views that make up the current debate on reforms and growth and Latin America, the arguments on which they are based, as well as possible limitations and objections of these arguments. A final section takes a view on what policy conclusions might reasonably be drawn from the material surveyed.

\section{THE FACTS}

\section{A. Growth Patterns in Latin America: Six Facts and a Conjecture}

The discussion that follows is organized in terms of six observations about output and growth in Latin America. The first three merely restate facts about average growth that are wellknown. The remainder are based on new research on output volatility and, finally, on real incomes measurement. Because the final point is based on evidence from only one country (Brazil) and its implications for GDP are still unclear, it is presented as a conjecture.

Fact 1. In the past 25 years, Latin American growth has generally underperformed relative to every other developing country region.

Figure 3 shows per capita growth in Latin America and four other regions-East Asia and Pacific (EAP), South Asia (SA), Middle East/North Africa (MENA), and Sub-Saharan Africa (SSAfr)-between 1970 and 2005, divided into six periods that broadly reflect boom-bust phases in capital flows to Latin America and emerging market countries more generally. The figure confirms that Latin America had fairly high growth in the 1970s compared with other developing country regions, second only to East Asia.

\footnotetext{
${ }^{2} 1970$ is chosen because it is the beginning of the period on which this paper focuses. This high-income country group includes the G-7, the Nordic European countries, the Benelux countries, Switzerland, Australia, and New Zealand.
} 
Since then, however, it has turned in the weakest growth of any developing country region, with more dramatic collapses in growth during bust phases, and less vigorous recoveries. There is one exception: the 1990-98 period, when Latin America grew more slowly than East and South Asia but faster than both Figure 3. Developing Country Regions: GDP Per Capita Growth, 1970-2005 Sub-Saharan Africa and

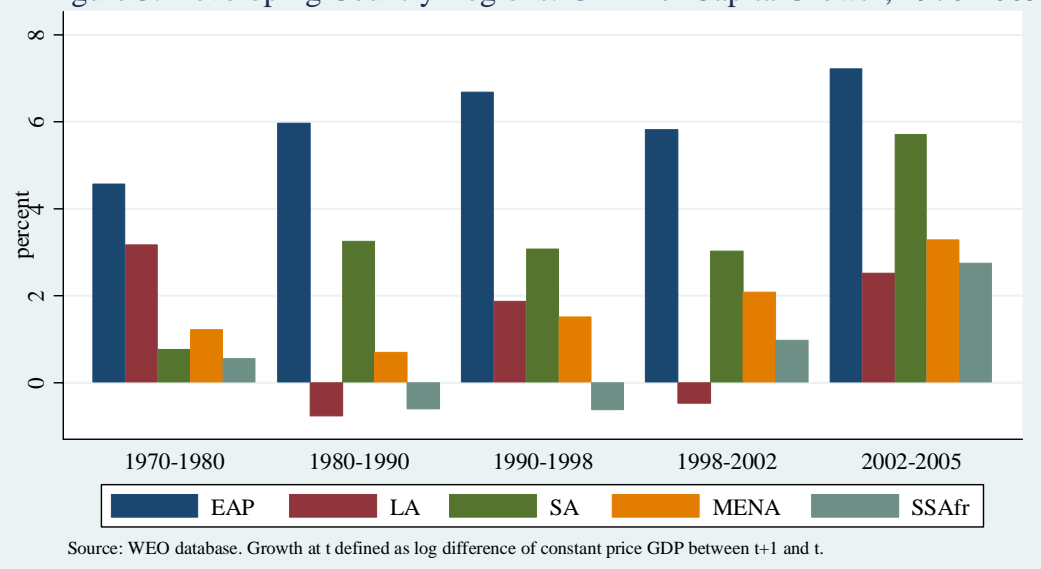
the MENA region. In the most recent recovery, however, Latin America has grown somewhat more slowly than any of these regions.

Fact 2. Slow GDP growth in Latin America has been driven by slow productivity (TFP) growth.

In an accounting sense, Latin American growth since the 1970s has been disappointing not because of low investment, low growth of the labor force or even low human capital accumulation, but because of declines in total factor productivity (TFP), that is, in the joint productivitylinked to the economy's technical or institutional capacity —of the "accumulable" factors of production. For example, growth in capital, and in human capital and labor was almost 4 percent per annum during the 1980 s (Figure 4). But output

Figure 4. Latin America: Growth Accounting by Decade, 1960-2000 (unweighted averages)

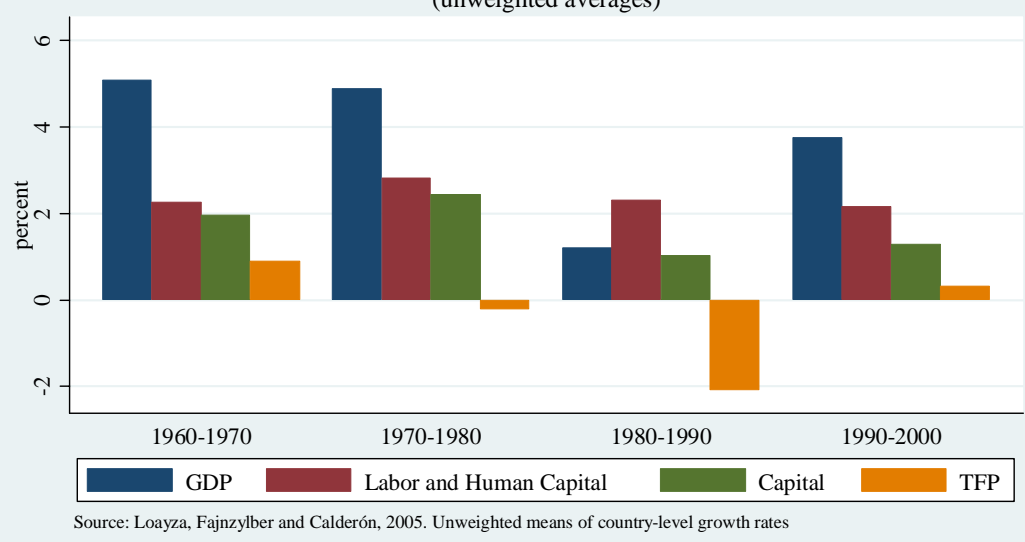
growth was a sluggish 1.5 percent on average in spite of these increases. This wedge is reflected in negative TFP growth.

It is also interesting to note that the high growth of the 1970s was due entirely to high capital accumulation and increases in labor and human capital. TFP growth in that decade was slightly negative on average, though there are large differences across individual countries (see Loayza, Fajnzylber, and Calderón, 2005, for details). 
Fact 3. Latin American countries exhibited roughly similar growth patterns until the 1980s, but more recently there have been large cross-country differences in growth performance.

With the exception of Venezuela and a few countries that suffered setbacks or crises (Bolivia, Chile, and the Dominican Republic), most Latin American countries grew fairly smoothly until the late 1970s, and there is a common pattern of stagnation and decline in the 1980s (exceptions: Chile, Colombia, and the Dominican Republic). Indeed, statistical tests detect a structural "downbreak" in growth in many countries around 1980, as shown by the solid vertical lines in Figure 5. In the 1990s however, growth performance was much more diverse. A few countries-Chile, the Dominican Republic, and until 1997, Argentinaenjoyed very fast growth (the latter two show statistical upbreaks around 1990). In contrast, in most countries, growth seems to have been positive though unspectacular. A few did worse: Ecuador's per capita income stagnated, and Venezuela continued its long decline (Figure 5).

Figure 5. Latin American Countries: Income Per Capita (at purchasing power parity, in logs; vertical lines denote structural breaks in the per capita growth series)
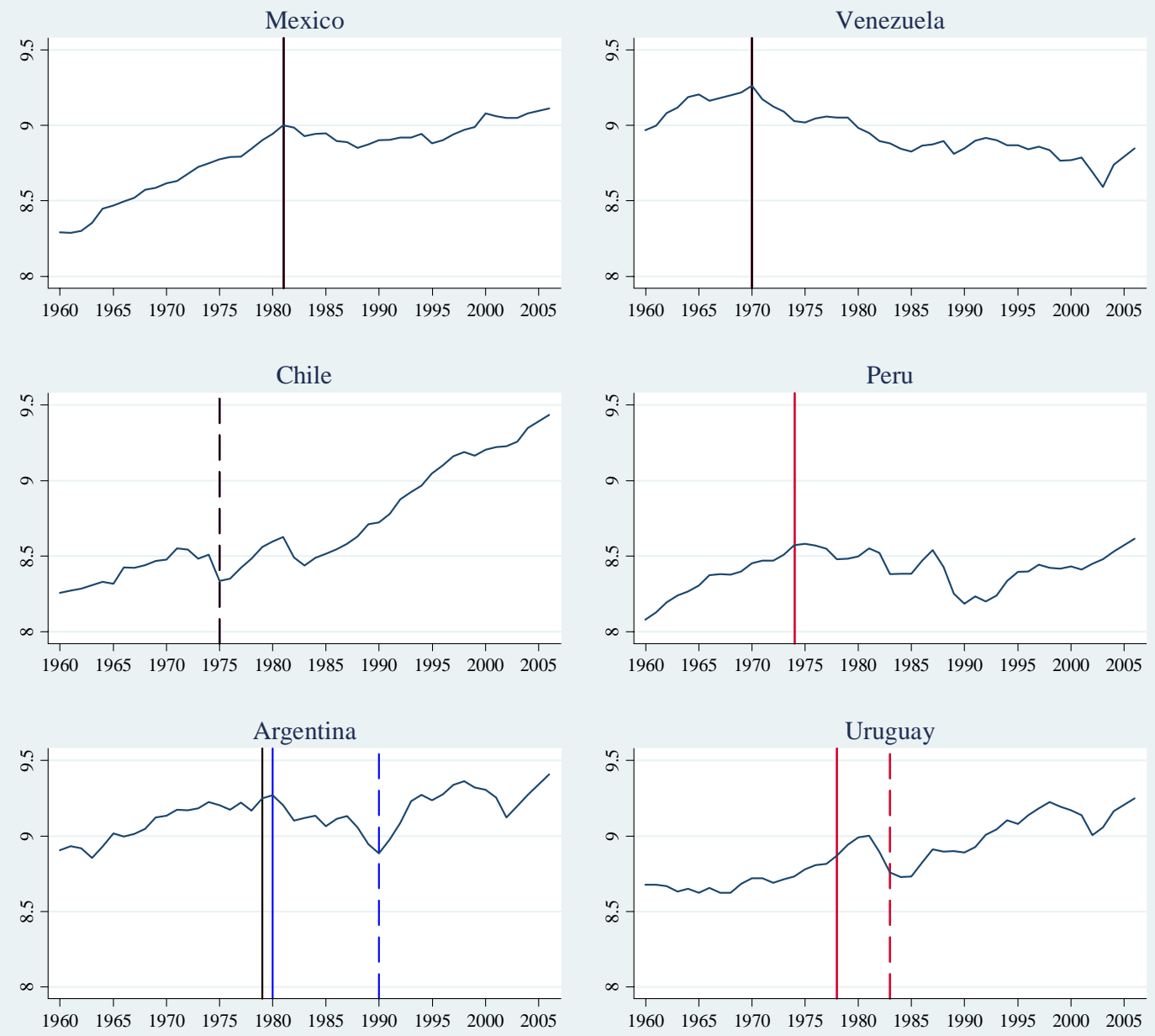

Breaks at $\mathrm{p}=0.10$ in black, $\mathrm{p}=0.25$ in red, and $\mathrm{p}=0.33$ in blue; dashes denote upbreaks. Source: Berg, Ostry, and Zettelmeyer, 2006 
Figure 5 (cont.). Latin American Countries: Income Per Capita (at purchasing power parity, in logs; vertical lines denote structural breaks in the per capita growth series)
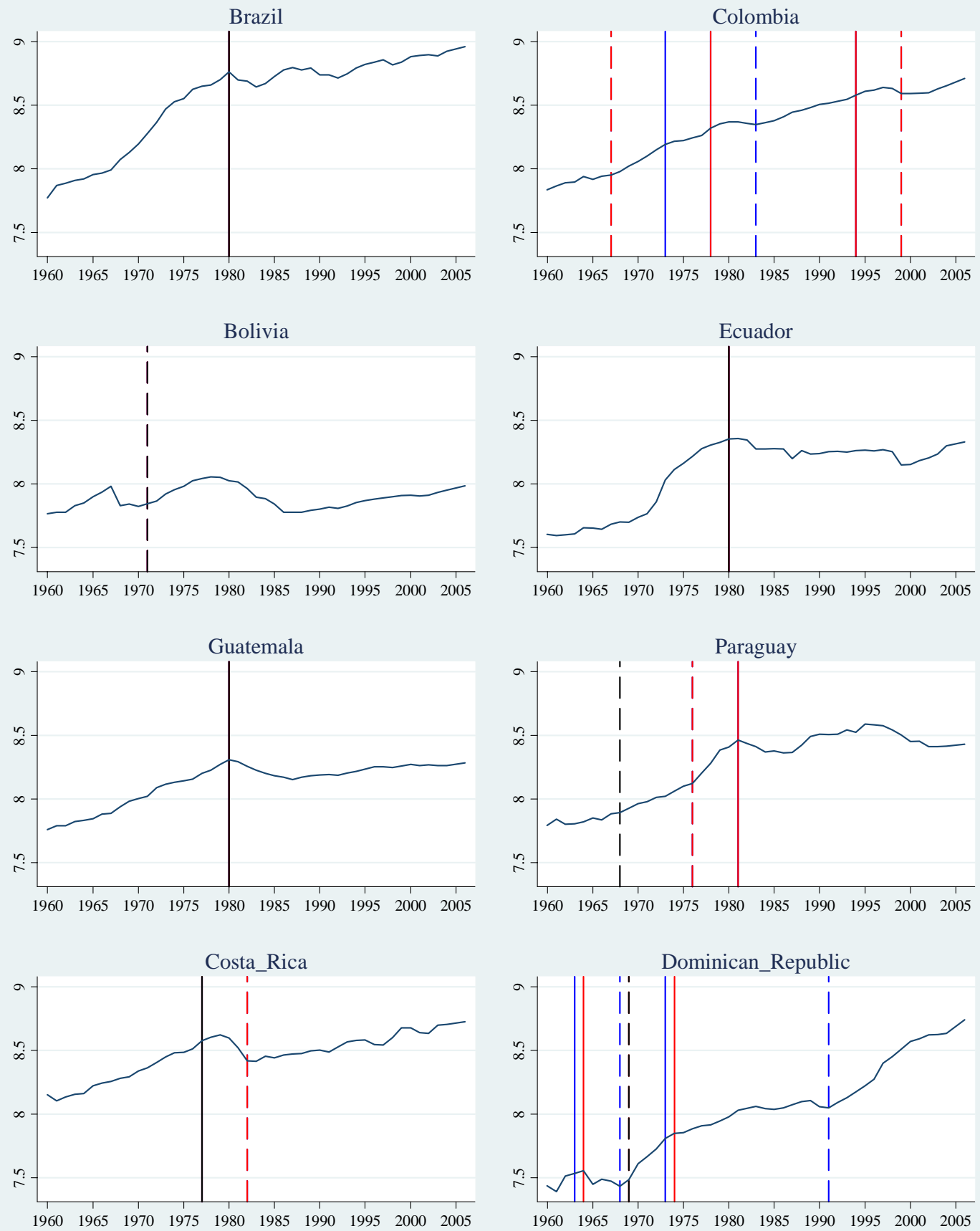

Breaks at $\mathrm{p}=0.10$ in black, $\mathrm{p}=0.25$ in red, and $\mathrm{p}=0.33$ in blue; dashes denote upbreaks. Source: Berg, Ostry, and Zettelmeyer, 2006 
So far, our emphasis has been on levels of output and growth. Given Latin America's large output collapses in the 1980s, and during the most recent crises in some countries, one would also expect the region to display high output volatility. Low growth and high volatility are indeed correlated at the country level, both across the world and within the region (Sahay and Goyal, 2006). As it turns out, however, average output volatility (as measured by the standard deviation of annual per capita real output growth) is not unusually high for Latin America compared with other regions. However, simple measures of this kind can be misleading, because they conflate year-to-year volatility in output (which is not very high in Latin America) with dramatic output drops during crises, as well as longer term volatility, at business cycle frequencies, and with respect to trend growth. Focusing on the latter, one does indeed see significant differences between Latin America and other regions, as follows.

Fact 4. Compared to both advanced countries and other non-Latin American emerging market economies, business cycles in Latin America are both more volatile and more protracted.

In a recent paper, Aiolfi, Catão, and Timmerman (2006) use a large set of aggregate and sectoral data series related to economic activity to construct business cycle indices for four Latin American countries-Argentina, Brazil, Chile, and Mexico-over a 135-year period. Their main result is that all four countries have historically displayed a striking combination of both business cycle volatility (large swings) and persistence (long cycles) relative to both advanced countries and some other developing country benchmarks. They also find that volatility has changed over time: it was highest during the open economy phase of the late 19th and early 20th century; declined markedly during the closed-economy/import substitution regimes between the 1940s and 1970, and bounced back again in the wake of the global shocks of the early 1970 until the late 1980s. Since then, volatility seems to have decreased to near historical lows in the cases of Brazil, Mexico, and Chile, in spite of the much higher trade and capital account openness in these countries (though it has remained high in Argentina — a reflection of the 2001-2002 crisis).

Fact 5. Latin America and Africa have suffered more frequent output collapses than other developing country regions (Figure 6).

Following a recent paper by Becker and Mauro (2006), we define output collapses as falls in output lasting at least two years and resulting in a total output loss of at least 5 percent. These cut-offs are arbitrary of course, but reasonable if the idea is to identify Figure 6. Frequency of Large Output Drops, by Region deep crises - far worse than mere recessions — that lead to large-scale job losses, sharp rises 
in poverty, corporate bankruptcies, and import collapses. Becker and Mauro (2006) show that for the twentieth century as a whole, the frequency of output collapses has been higher in Latin America than in any other region, driven mainly by the Great Depression, and the debt crisis of the 1980s. As to the period after World War II, Latin America turns out to be the world's most unstable region in two out of five decades - the 1980s and the 1950s — and the "runner up" in two others - the 1970s and 1990s (Figure 6). Only during the 1960s was the frequency of output collapses in Latin America low compared with other regions.

Fact 6. Growth spells-periods of high average trend growth-have been shorter lived in Latin America than in other regions.

Suppose a country has been enjoying an extended period of high trend growth. What is the probability that this "spell" will end, i.e. that the country will experience a downward shift in average growth? How long do periods of high trend growth typically last? To address these questions, one can identify structural breaks — statistically significant shifts - in average country growth, and use these to define a "growth spell" as a period of high growth (say, in excess of 2 percent per capita per annum) that either ends with a structural downbreak or with the end of the sample period (see Berg, Ostry, and Zettelmeyer, 2006). This approach will filter out business cycles and other short-lived bursts of growth, enabling a focus on a country's or region's ability to sustain growth over the medium and long term.

Table 1, adapted from Berg, Ostry, and Zettelmeyer (2006), compares the average duration of growth spells for three developing country regions: Latin America, Asia, and Sub-Saharan Africa. If one considers all growth spells-including periods of high growth that began before 1950, which is the beginning of the sample period here - then the average length of growth spells is high in all regions. This is because the long, steady growth spells of the immediate postwar period, which mostly ended in the 1970s or early 1980s, are included in the sample. Even so, however, the average length of growth spells is lower in Latin America than in the other two regions. The contrast is sharpened if one considers only growth spells that were initiated after 1950, when countries began to grow rapidly after a period of previous sluggish growth. In this case, the average length of a growth spell in Latin America is only half of that in Asia, and lower even than in African countries (though growth spells tend to be more frequent in Latin America than in Africa).

Table 1. Frequency and Duration of Growth Spells $\underline{1} /$

\begin{tabular}{|c|c|c|c|c|c|}
\hline \multirow[t]{2}{*}{ Region } & \multirow[t]{2}{*}{$\begin{array}{c}\text { No. of } \\
\text { countries }\end{array}$} & \multirow[t]{2}{*}{$\begin{array}{l}\text { No. of } \\
\text { spells }\end{array}$} & \multirow[t]{2}{*}{$\begin{array}{c}\text { Mean } \\
\text { duration }\end{array}$} & \multicolumn{2}{|c|}{$\begin{array}{c}\text { \% spells } \\
\text { of length > }\end{array}$} \\
\hline & & & & 9 years & 15 years \\
\hline & \multicolumn{5}{|c|}{ All Growth Spells } \\
\hline Latin America & 18 & 19 & 19.1 & 79 & 58 \\
\hline Emerging Asia & 16 & 17 & 32.2 & 82 & 82 \\
\hline \multirow[t]{2}{*}{ Sub-Saharan Africa } & 42 & 33 & 19.9 & 85 & 61 \\
\hline & \multicolumn{5}{|c|}{ Spells initiated after 1950 only } \\
\hline Latin America & 18 & 10 & 13.9 & 70 & 30 \\
\hline Emerging Asia & 16 & 11 & 26.1 & 73 & 73 \\
\hline Sub-Saharan Africa & 42 & 13 & 15.2 & 69 & 38 \\
\hline
\end{tabular}

The final point in this section concerns growth measurement. Because it is based on firm evidence from one country only, it is framed as a conjecture rather than as fact. 
Conjecture. In Latin American countries that underwent large trade liberalizations, real income may subsequently have risen much faster than the official numbers show.

The starting point for the conjecture is that in some reforming countries, reported real income changes seem inconsistent with observed improvements in social indicators, and shifts in consumption behavior. For example, reported per capita growth in Brazil during the 1990s, following trade liberalization in the early 1990s and stabilization in 1995, was just a little over 1 percent per annum on average. At the same time, however, the food share in consumption expenditures dropped dramatically —at all income levels, but particularly at the bottom of the distribution, where it fell as much as 15 percentage points. This is hard to reconcile with the view that real incomes changed little. The fact that food shares in consumption decline as individuals become richer is one of the oldest and most stable empirical regularities in economics (“Engel’s Law”).

In a recent paper, de Carvalho Filho and Chamon (2006) propose a solution to this puzzle: real income gains may have been underestimated, in essence, because nominal incomes were deflated too much, due to infrequent updating of the consumption bundle underlying the CPI at a time in which the economy was going through a dramatic external opening. Average tariffs dropped from about 120 percent in 1987 to 13 percent in 1997, resulting in substitution of consumption toward much cheaper tradable goods, as well as new goods, many of which were not reflected in the CPI basket until 1999. In other words, consumers in the 1990s were buying a different—cheaper and better—consumption bundle than assumed by the CPI, and their real incomes were correspondingly higher. The magnitude of the effect appears to have been quite dramatic. Based on the observed drop in food shares in total expenditure-and taking into account the relative price changes that were taking place at the time-de Carvalho and Chamon (2006) estimate average annual real growth of household income about 3.6 percentage points above that indicated by the standard measures.

Two questions are still open at this point, however. First, does the finding carry over to other countries in the region? To the extend that import barriers were rapidly removed while CPI baskets were updated infrequently, one would expect so, though perhaps less dramatically than Brazil, whose economy had been closed to a large range of imports. Second, to what extent does de Carvalho and Chamon's argument apply to GDP measurement rather than just real income measurement based on household survey data? As in many other countries, GDP statistics in Brazil attempt to "reconcile" production and demand-side estimates. The latter are vulnerable to de Carvalho and Chamon's measurement problem, because the CPI is used to deflate private consumption. What is not clear is the extent to which this has affected GDP numbers in the past. Hence at this point we do not know to what extent de Carvalho and Chamon's findings are a statement about the measurement of living standards given real GDP growth, and to what extent they apply to measured real GDP growth itself.

\section{B. Growth Covariates}

We now turn to the correlates of economic growth-the political, social, and economic variables that are thought to influence growth, though the causality will often run both ways. We organize these correlates in a way that is familiar from the empirical literature, beginning 
with suspected "deep determinants" of growth—institutions, openness and trade; education and health; and economic inequality — and continuing with macroeconomic policies and financial crises, that could be symptoms of the deeper factors but also affect economic growth directly. Finally, we examine Latin America's exposure to external shocks, which have often been blamed for its economic problems. To get a sense both of how these growth correlates have changed over time-including, perhaps, as a result of reforms — and how Latin America compares with other regions, the focus is on regional averages of these variables over the 1970-2005 period or even longer, data permitting. For clarity, we focus on just four country groups: high-income countries as defined by income status in 1970 ("H70", see footnote 2), a group comprising both East Asian and South Asian countries (except for Japan, which is in the high income group); Latin America (“LA”), and Sub-Saharan Africa ("SSA"). ${ }^{3}$

Figure 7 compares institutions from four angles: the degree to which political institutions are democratic; the quality of legal institutions and the security of property rights; the presence of corruption; and the quality of the bureaucracy (the two latter could be thought of as alternative proxies for the quality of economic institutions). The figure carries two main messages. First, the quality of institutions in fast-growing Asia does not seem clearly superior to that of Latin America. Of the four indicators shown, Asia seems to have performed consistently better only in one dimension, namely, the quality of its public sector. Second, Latin America seems to have improved over time in all four areas, though there seem to have been recent reversals in two (property rights, and corruption). In one areademocracy — the improvement has been dramatic: since the mid-1970s, Latin America has gone from one of the world's most autocratic regions to one of its most democratic. Similar improvements have been made in related indicators that are sometimes linked to growth, such as constraints on the executive or political participation (not shown).

\footnotetext{
${ }^{3}$ Regional averages are for fixed country groups over time, to avoid changes in the time paths due to exiting or entering countries. As a result, the membership of the regional groups differs somewhat across graphs, as countries with incomplete data over the time path were excluded. The number of countries in each group is given at the bottom of each chart.
} 
Figure 7. Institutions
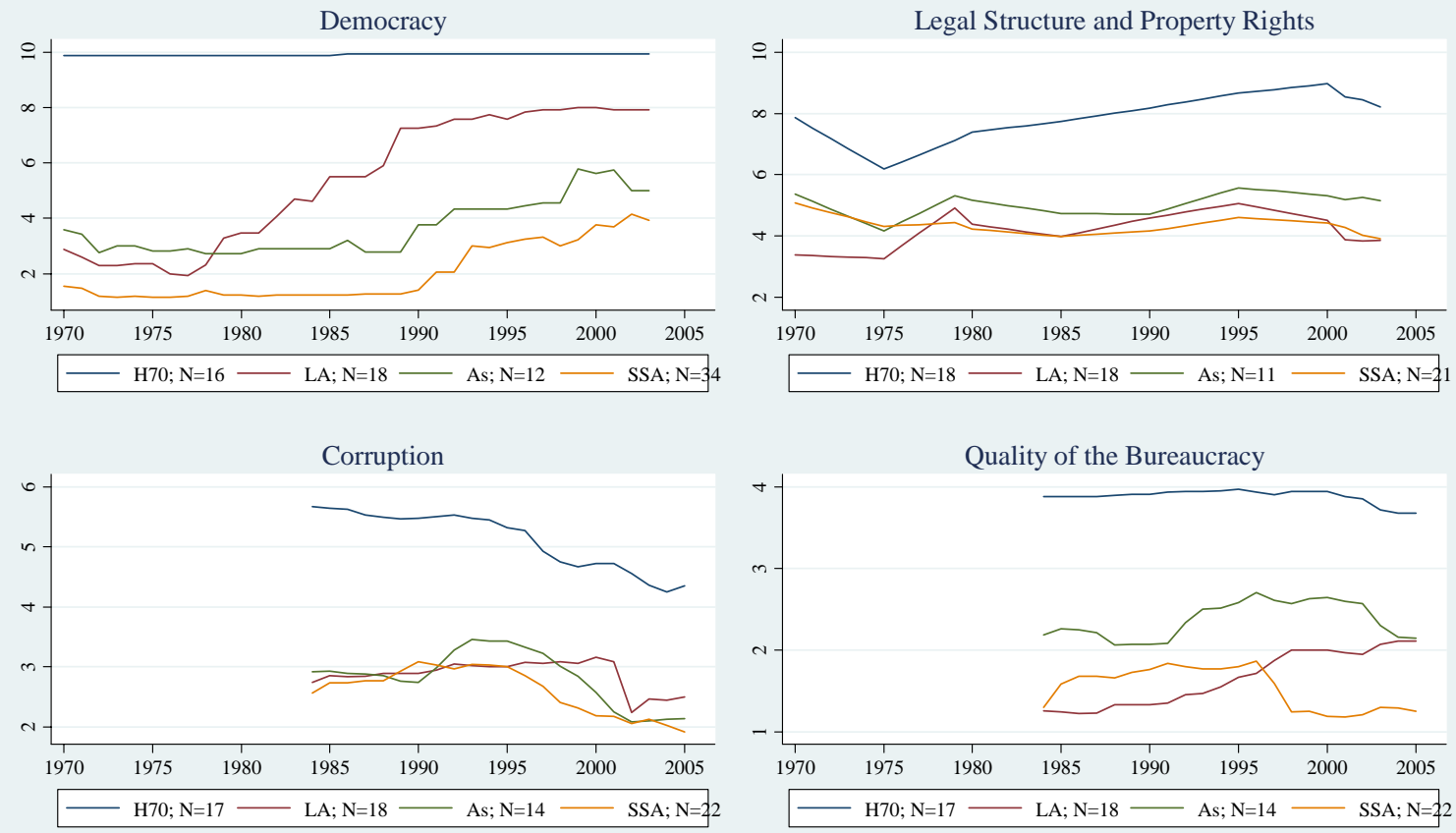

Sources: Polity IV database; Cato Institute; International Country Risk Guide (for Corruption and Quality of Bureaucracy indices).

Next, consider Latin American performance with respect to a set of social indicators that are often regarded as important for growth, namely education, health, and inequality. Simple education and health indicators in Asia and Latin America turn out to track each other closely. Significant progress has been made in both regions since the early 1970s, though this does not capture differences in the quality of education. ${ }^{4}$ In contrast, the difference between Asia and Latin America with respect to income inequality is very large. In order to be able to show a long and up-to-date series, the bottom-right chart in Figure 8 simply plots average country Ginis over time (as opposed to regional Ginis based on a regional income distribution; see, for example, World Bank, 2004, Table A18). The figure confirms the wellknown fact that Latin America has been the most unequal region in the world; ${ }^{5}$ furthermore, it suggests that it has become more unequal over time.

\footnotetext{
${ }^{4}$ Latin American countries do significantly worse than Asia when education measures such as average hours of schooling or enrollment rates are adjusted by per-capita income levels. Furthermore, Latin American secondary school students perform relatively badly on standardized tests (De Ferranti et al., 2003).

${ }^{5}$ The figure shows the average African Gini tracking and occasionally surpassing Latin America's. However, the sample for Africa is very small (14 out of 42 countries) due to difficulties in obtaining long series of Ginis for African countries. Studies that pool income distribution data over time and countries report average African Ginis in the order of 46-48 percent—not quite as high as Latin America’s.
} 
Figure 8: Social Indicators
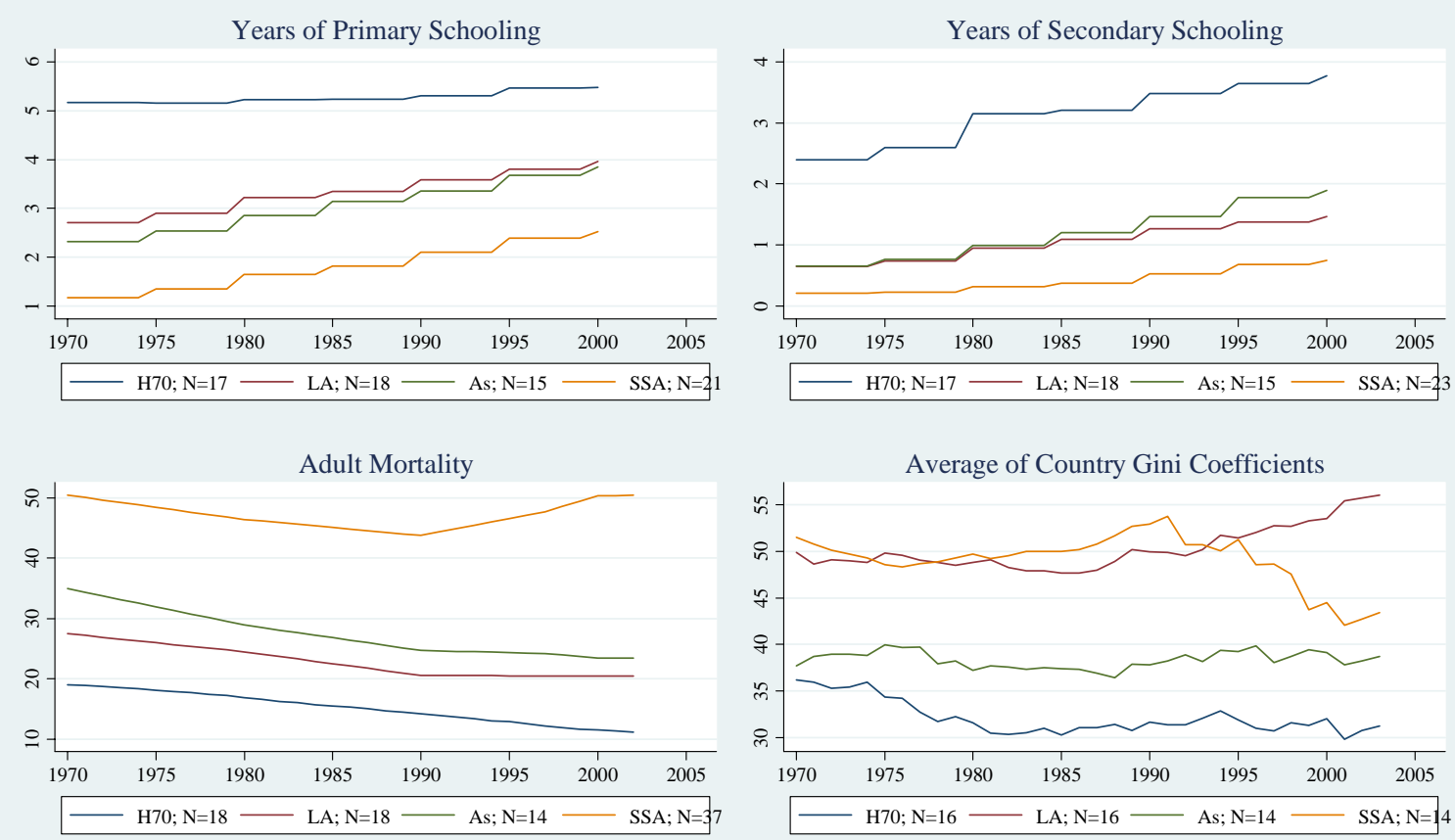

Sources: World Bank for Schooling and Mortality data; WIDER for inequality data.

Openness and Trade have also often been linked to high growth, particularly in the context of the East Asian growth miracle (Figure 9). The upper two panels show trade-related variables that are entirely or partly under the control of policy: trade liberalization, and overvaluation, the latter measured as deviations from purchasing power parity that cannot be explained by relative productivity. ${ }^{6}$ The lower two panels show outcomes. The main result is that in spite of its extensive trade liberalization in the late 1980s and early 1990s, the region's openness to trade has increased only slowly: the region remains the most closed developing country region in the world whereas Asia is by far the most open region. ${ }^{7}$ Another difference is the dramatic rise in the manufacturing share in total Asian exports. For Latin America, this share was flat until the mid-1980s, after which it started rising, albeit slowly. Finally, while Latin America's exchange rates do not appear to have been overvalued on average, there have been large swings in competitiveness, with protracted cycles of depreciation and appreciation. In contrast, we observe persistent average "undervaluation" in Asia-that is, lower price levels than can be explained through per capita income alone.

\footnotetext{
6 “Overvaluation” consists of the residuals from year-by-year cross-sectional regressions of log price levels relative to the United States on the log of PPP-adjusted per capita income.

${ }^{7}$ Following Pritchett (1996) and many others, openness is defined here relative to the openness of other countries of similar size and transport cost. That is, "openness" is the residual from regressions of the sum of exports and imports over GDP on log population, area, a "landlocked” dummy, log per capita income, a "remoteness index" and an oil dummy. The "city economies” Singapore and Hong Kong SAR are excluded. Using unadjusted openness and/or including Singapore and Hong Kong SAR would give qualitatively similar results, but show even more dramatic differences between Asia and Latin America.
} 
Figure 9: Openness and Trade
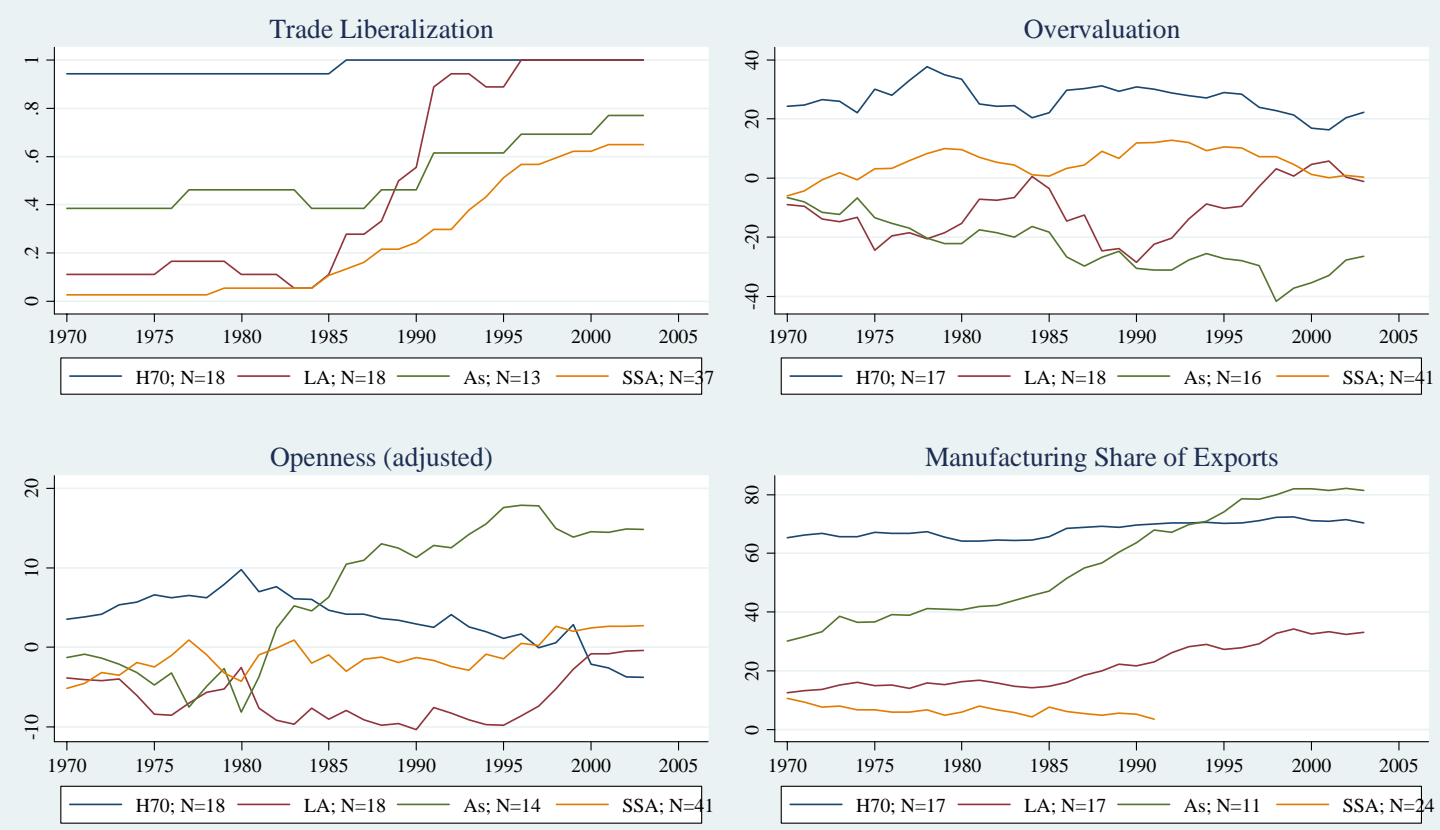

Sources: Wacziarg and Welch (2003) for trade liberalization; Penn World Tables and author's calculations for overvaluation and opennness; World Bank.

Macroeconomic policies could be relevant for growth through many channels-including inflation, debt, tax policies and spending policies - though the strength and robustness of these effects recently been controversial (Easterly, 2005). ${ }^{8}$ Figure 10 shows how some of these variables have evolved in Latin America and other regions. As is well known, Latin America was a high-inflation region until recently, with some countries suffering hyperinflations until the early 1990s. Since then, however, inflation has been brought down to single digits in almost every country in the region. ${ }^{9}$ Similarly, average public debt levels have come down significantly from very high levels in the late 1980s (though Figure 10 exaggerates the drop because it only includes external public debt for the developing countries, and thus misses the sharp rise of domestically issued public debt in the second half of the 1990s). ${ }^{10}$

8 References include Fischer (1993), Bruno and Easterly (1998) and Ghosh and Phillips (1998) on inflation and growth; Cohen (1997), Pattillo, Poirson, and Ricci (2002), Cordella, Ricci, and Ruiz-Arranz. (2005) and Benelli (2006) on debt, and Easterly and Rebelo (1993a, 1993b) on fiscal policy.

${ }^{9}$ In some countries, this reflected institutional improvements in monetary policy making (Carstens and Jácome, 2005).

${ }^{10}$ Public debt figures for developing countries are not available for the long time period that we seek here, although two recent studies_-Jeanne and Guscina (2006), and Jaimovich and Panizza (2006)_have put together data for the 1990s. Domestically issued public debt is negligible in most low income countries, but it constitutes an increasingly share of public debt (20-60 percent) in Asian and Latin American emerging market economies. According to Jaimovich and Panizza (2006), Latin American public debt stabilized at 50-60 percent of GDP in the 1990s (unweighted country mean). 
Figure 10: Macroeconomic and Public Expenditure Policies
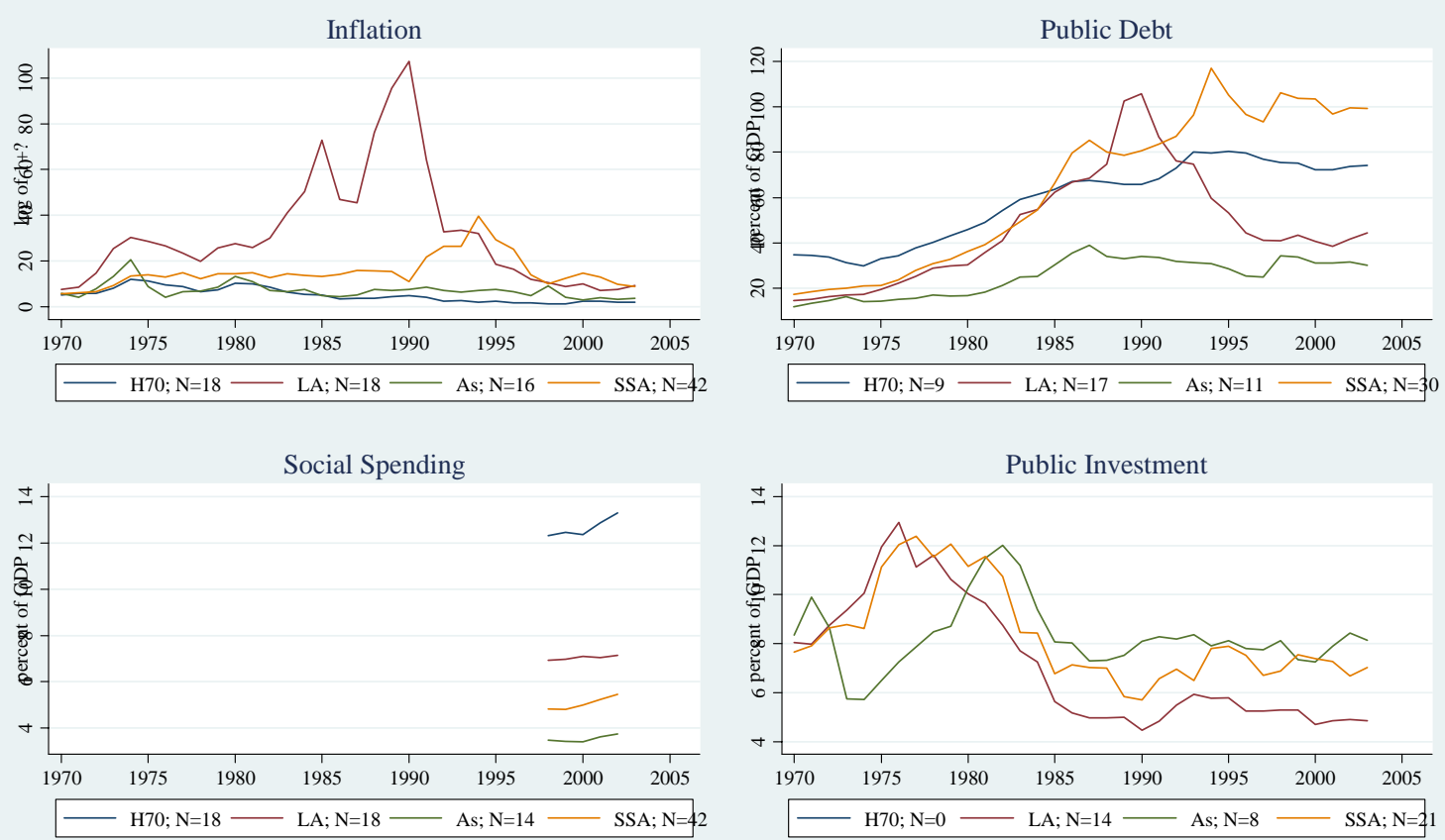

Sources: IMF (World Economic Outlook) for inflation, public investment, and H70 debt data; World Bank for social spending and non-H70 debt data

The lower half of the figure shows data on government spending in specific areas. Unfortunately, data on social spending (here: the sum of spending on health and education, from the World Bank's WDI database) are available only for a wide cross-section of countries since the late 1990s, i.e. Latin America's post-reforms period. According to this snapshot, social spending is higher in Latin America than in both Asia and Africa. Finally, the bottom right figure shows that public investment in Latin America was high and rising in the 1970s, collapsed in the 1980s, and recovered slightly in the 1990s. It remains low, however: about 5 percent of GDP (unweighted average), compared to about 8 percent for the Asian countries.

Figure 11 looks at crises, both financial and political. The top two graphs, dealing with the average frequency of currency and debt crises (per country and year), confirm Latin America's status as the traditionally most financially unstable region in the world, but they also show that the regions became more stable in the 1990s, both in absolute and relative terms. Currency crises are defined here as large devaluation events (as in Frankel and Rose, 1996), while debt crises refer not just to episodes of restructuring but also to "debt distress" more generally (see Becker and Mauro, 2006, for sources and definitions). Criteria focused on sovereign debt restructurings would show Latin America to be the most crisis-prone region even in the most recent period. ${ }^{11}$ The bottom two charts show that Latin America has

\footnotetext{
${ }^{11}$ Three of the six major sovereign debt restructuring episodes since 1998 (in Ecuador, Argentina, and Uruguay) took place in Latin America. See Sturzenegger and Zettelmeyer (2006).
} 
suffered its share of wars and political reversals (the latter defined as a drop of at least 3 points in the 20 point "polity index" measuring the openness of political institutions to participation; see Marshall and Jaggers, 2003) but not more so than other developing country regions, including Asia.

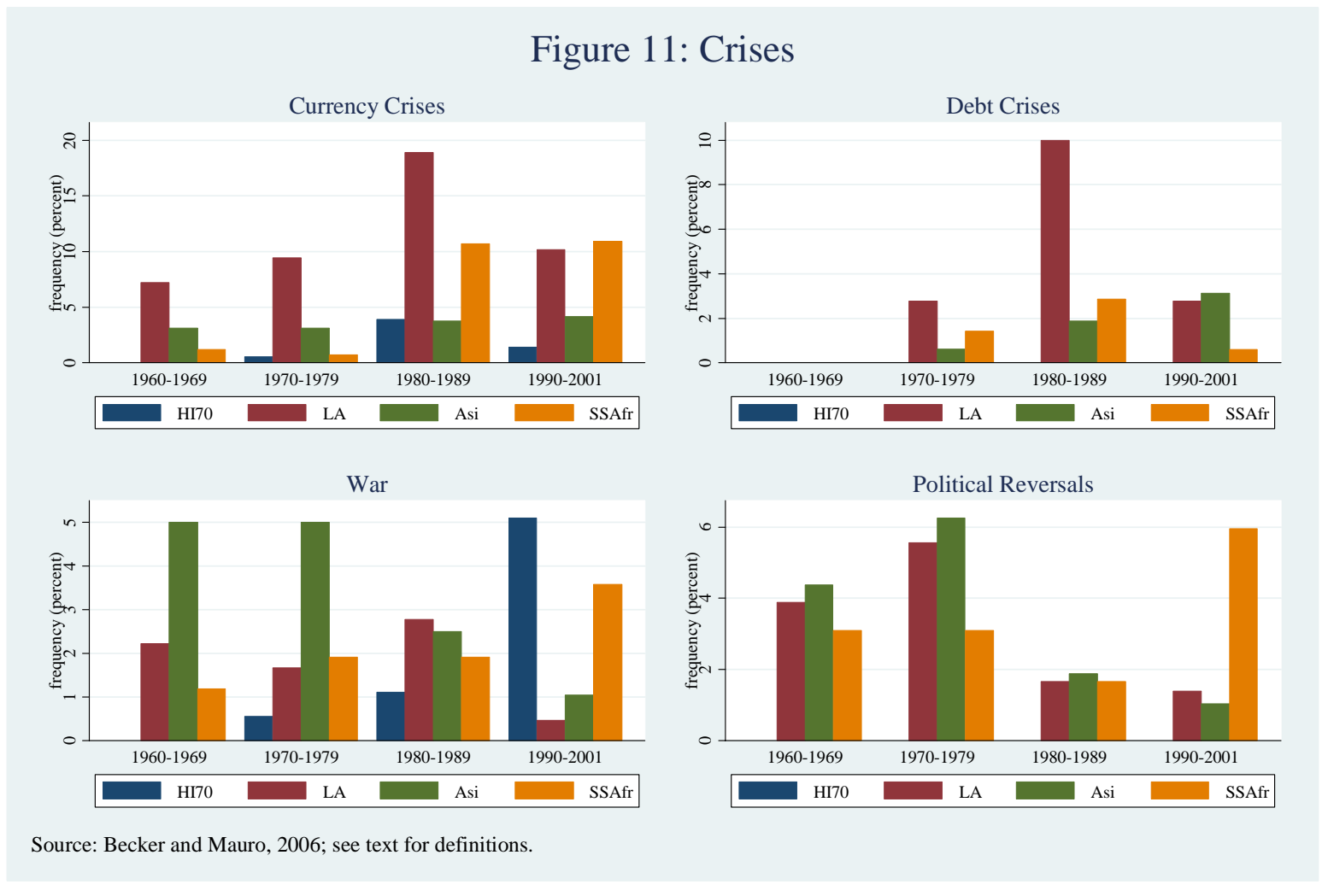

Finally, a critical question is obviously whether Latin America's high macroeconomic volatility and frequent financial crises were predominantly due to poor policies and institutions, or whether they were the result of external or domestic shocks outside the control of policymakers. Answering this question is outside the scope of this paper (see Sahay and Goyal, 2006, for a recent study) but it is nevertheless interesting to see whether Latin America was unusually hard-hit by output-reducing shocks compared to other regions.

Figure 12 starts with the question whether the evolution of its terms of trade since 1970 has put Latin America at a disadvantage relative to other regions. The answer is "no," but it is also clear from the picture that regional growth was highly correlated with its terms of trade. The high-growth decade of the 1970s coincided with a terms of trade boom; the catastrophic 1980s with a terms of trade bust, and the 1990s with a slow recovery-punctuated by a terms of trade dip in the late 1990s - that continues today. Figure 12 also shows that the region's terms of trade have been more volatile than in other regions except Africa (upper right figure). Disasters (natural disasters and industrial accidents above a certain threshold in terms of life loss) have been fairly frequent, but less so than in Asia in the 1960s and 70s, and less than in Africa in the 1990s. Finally, in the 1980s and 1990s, both Latin America and Africa suffered from frequent "sudden stops" in cross-border capital flows, defined as a worsening 
of the financial account balance of at least 5 percentage points of GDP relative to the previous year. Whether these reversals were "exogenous" in the same way as disasters or terms of trade shocks is of course open to question.

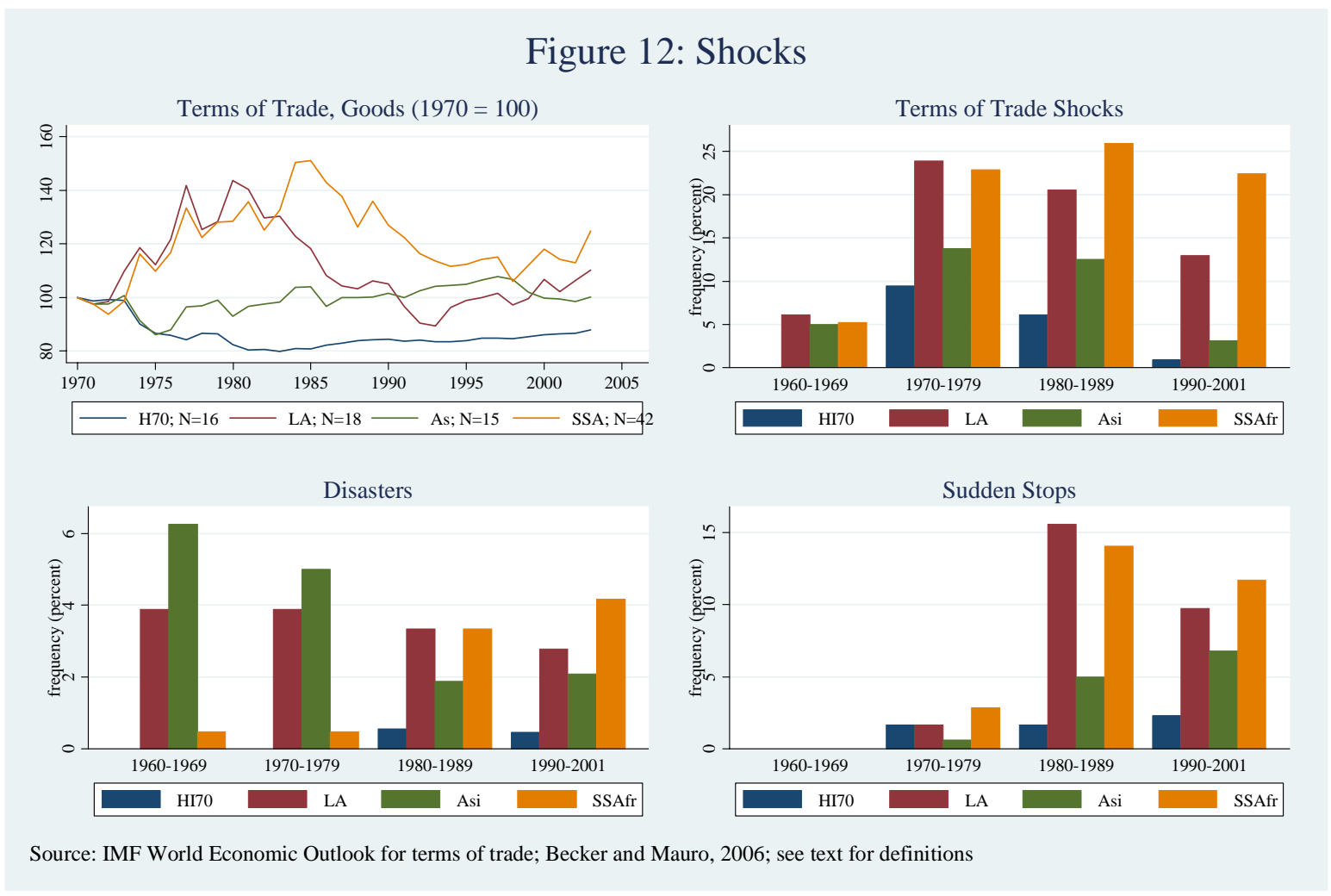

In sum, Latin America stands out with respect to financial crises and macroeconomic volatility, though for the region as a whole, the 1990s were a more stable period than the 1980s. Indeed, by some measures_-including inflation, and business cycle volatility in the countries that managed to avoid crises during 1998-2002 - the 1990s were more stable than the 1970s. Given the fact that Latin America was much more open and exposed to capital flow reversals in the 1990s, and that the terms of trade were far less favorable than in the 1970s, this is quite remarkable.

\section{The ARguments: Why DID Reforms Not LEAD TO Higher GROWTH?}

By the late 1990s, it was apparent that post-reforms growth rates in Latin American countries - at least as measured by the official statistics - were generally disappointing, certainly by Asian standards, and also by the standards of a few fast growers in the region itself, such as Chile, or Argentina prior to 1998. This gave rise to an outpouring of writing on the subject, together with a public policy debate on the role of reforms. The debate intensified after a series of balance of payments crises-beginning with Brazil and Ecuador in 1998-99, and ending with Argentina and Uruguay in 2001-02-temporarily halted growth in the region. Had reforms in Latin America failed, and if so, in what sense and why? 
What follows is a selective survey of this debate, in the form of a taxonomy of proposed explanations for why reforms have not led to higher growth in Latin America. First, there is the view, common among academic economists, international organizations, and some Latin American policymakers, that reforms did in fact have the desired effects, but were simply not deep, broad, or sustained enough to raise growth to the desired level. Second, there is the opposite view: that reforms went to far, or were altogether harmful. The supporters of this view include left-of-center political movements in the region, some think tanks, and academics critical of globalization. Third, there is a recent view-originating from academia, but increasingly widespread, including in international organizations - that argues that neither of the first two views is right. In this view, reforms have failed to produce the desired growth rates not because they were too weak or harmful, but because they missed the point, in the sense that they failed to relax the critical constraints that hold back growth.

For clarity and dramatic effect, this taxonomy of views is set up in a way that makes them appear mutually exclusive. As the reader will soon discover, however, this is not strictly speaking true. For example, it is possible that reforms did not go far enough in many areas, but too far in some. It is also possible to believe that past reforms were generally necessary and desirable, but that further growth requires reforms of a different kind, or a different approach altogether. In practice, we are likely to see most overlap between the first and third views, though one can also pinpoint scholars and analysts of the region that would find areas of agreement with both the second and third, and indeed with both the first and the second.

\section{A. “Reforms Did Not Go Far Enough"}

Two academic literatures have been used to back the view that reforms simply did not go far enough, and that they can therefore be expected to keep their promise provided they are deepened (and possibly broadened). The first is based on industry-level studies, the second on regressions relating cross-country growth performance to macroeconomic and structural characteristics of the countries.

\section{Industry-Level Evidence}

A number of industry-level case studies (see Cole and others, 2005, for a summary and references) show that labor productivity of industries that were privatized or opened to international competition rose sharply, exactly as these reforms had intended. Examples include the opening of Chile's copper industry to foreign competition, the elimination of quotas prohibiting computer imports to Brazil, the privatization of the Brazilian iron ore industries, and large-scale privatizations in Argentina and Mexico. Conversely, in industries that were nationalized, or where competition was restricted, output and productivity fell.

Since low per capita growth in Latin America is essentially a problem of low productivity growth, this is prima facie evidence that the desired link between reforms and growth has in fact been present. Hence, these studies give backing to two cornerstones of the original "Washington consensus": privatization and trade liberalization. In addition, to the extent that the channel through which these reforms affected productivity is increased competition, studies of this type help to explain why economy-wide growth has not uniformly taken off: 
even after external barriers to competition have been removed, internal barriers to entry and competition may remain in many countries and industries, in the form of bureaucratic red tape, shallow financial markets which limit investment, and inflexible labor markets. Djankov and others (2002) cite evidence suggesting that business start-up costs remain much higher in Latin America than in the United States, Europe, or Asia. Together with the success of competition-creating policies in sectors that were privatized or liberalized, this constitutes a powerful argument in favor of both deepening and broadening of reforms, in the direction of further liberalization and privatization, financial market deepening, and labor market reforms.

This said, studies that establish a link between reform and growth based on industry-level evidence suffer from two limitations. First, they do not easily allow a distinction between "level effects" and "growth effects." In other words, it is not clear whether increases in competition in a particular industry lead only to a one-time increase in productivity, or whether they also lead to a permanent increase in productivity growth. Second, industry-level studies cannot gauge the economy-wide growth benefits of particular reforms. Quantifying these benefits is the subject of macroeconomic studies, in particular, regression analyses that compare experiences across countries.

\section{Cross-Country Growth Regressions}

Cross-country growth regressions relate growth outcomes to domestic economic fundamentals (including, in some cases, measures of institutional quality), initial income per capita, and external factors such as terms of trade shocks and world growth trends. The basic approach behind these regressions goes back to Barro (1991), but has been increasingly refined in recent years (in particular, by better separating cyclical recoveries from trend growth, and by attempting to deal with "reverse causality," i.e. disentangling the impact of economic fundamentals on growth from possible feedback from growth to fundamentals). Since the mid-1990s, there has been a large number of academic papers that have used this approach to analyze growth patterns in Latin American countries, compare them with those of other regions, and-on the assumption that changes in measured economic fundamentals reflect economic policies, including structural reforms-estimate the growth impact of reforms. ${ }^{12}$

The results of this research uniformly back the case that reforms have been good for longterm growth. First, variables reflecting economic policies and structural reforms-measures of economic instability such as inflation, the black market exchange rate premium or crisis indicators; government consumption; trade openness; financial depth; education; and infrastructure-are generally both statistically and economically significant, with the expected signs (negative for macroeconomic instability and government consumption, positive for the others). Second, the models do a reasonable job at explaining growth both

\footnotetext{
${ }^{12}$ Widely cited contributions include: Easterly, Loayza, and Montiel (1997); Fernández Arias and Montiel (2001); De Gregorio and Lee (2003); Blyde and Fernández Arias (2004); and Loayza, Fajnzylber, and Calderón (2005). See also Adrogué, Cerisola, and Gelos (2006).
} 
across countries and over time. For example, according to Loayza, Fajnzylber, and Calderón, (2005), macroeconomic stabilization and improvement in variables related to structural reforms lifted growth in Latin America in the 1990s by about 2.5 to 3 percent per annum, on average, relative to the 1980s. The regressions are also successful in explaining a portion of the growth gap between Asia and Latin America. According to Blyde and Fernández Arias (2004), differences with respect to inflation performance, openness, and institutional quality (measured by a variable capturing economic and political risk) can be blamed for about 2.2 percentage points of the approximately 2.5 point gap in average annual TFP growth between East Asia and Latin America during the 1970-2000 period. Lack of openness turns out to be the single most important factor harming Latin American growth performance relative to East Asia, with a contribution of 1 percent. De Gregorio and Lee (2003) obtain broadly consistent results for regressions involving per capita growth; in their analysis, about 1.6 percent lower per capita growth is attributable to policies and institutions, of which 0.6 percentage points are due to differences in openness.

At the same time, stabilization and reforms of the early and mid-1990s have hardly exhausted the potential for better economic policies in Latin America. In particular, the region has continued to suffer from large bouts of macroeconomic instability, during the 1994-95 Tequila crisis, and later from 1998 to 2002. While these setbacks were to some extent triggered by external shocks, the vulnerability to these shocks (in particular, in the form of the size and structure of the public debt) was homegrown. Furthermore, structural reforms in Latin America are by no means complete (Lora, 2001). Most progress has been made in the area of trade liberalization. But other areas, such as financial deepening, privatization, and tax reforms have seen only limited progress, and in some areas, most notably labor markets, there have been no reforms. Combined with the results of the cross-country regression literature, this leads to a straightforward argument in favor of further reforms. If differences in fundamentals related to reforms can have a substantial impact on growth, and plenty of scope remains for further reforms, there would seem to be a straightforward case for locking in macroeconomic stability; broadening reforms; and deepening them in areas in which they remain partial (see, for example, Krueger, 2004; Singh and others, 2005).

The argument that stabilization gains should be "locked in" does indeed enjoy broad support. ${ }^{13}$ However, the call for additional, across-the-board structural reforms has been controversial. Some of the opposition to reforms is rooted in ideology (see next section below). But some of it is also based on perceived flaws in the intellectual argument for broad further reforms, and some has in fact originated from the ranks of economists that are firmly within the mainstream of the profession. ${ }^{14}$ The criticisms from these quarters are as follows.

\footnotetext{
${ }^{13}$ There remains a controversy as to what stability exactly means; in particular, whether moderate inflation in excess of low single digits is harmful to growth or not. See Bruno and Easterly (1998), Ghosh and Phillips (1998) and Easterly (2005).

${ }^{14}$ Examples include former IADB Chief Economist Ricardo Hausmann, and Chile’s current Minister of Finance, Andrés Velasco.
} 
First, there is the issue whether the glass of reforms - or more precisely, that of their contribution to growth — should be viewed as half-full or half-empty. Our summary so far has emphasized that the glass is half full. But the same results can be viewed differently. For example, about half of the 2.5-3 percentage point per capita growth gain that Loayza, Fajnzylber, and Calderón (2005) attribute to better policies and reforms in the 1990s is due to macroeconomic stabilization from very high to moderate or low inflation rates: hopefully, a one-time event. The remaining growth improvement-the portion that could be attributed to structural reforms - no longer seems that impressive: about 1 percentage point per annum for Argentina, 0.9 for Brazil, and 1.5 for Mexico. A similar picture arises from the comparison between Latin America and East Asia. According to De Gregorio and Lee (2003), bringing key structural growth determinants-government consumption, the rule of law, and openness - to East Asian levels in the 1990s would have added 1.3 percentage points per annum to Latin America's growth rate. This is not bad, but neither is it the "the sort of result that drives reform advocates wild with excitement” (Hausmann and Velasco, 2005).

Second, the literature discussed so far does not, strictly speaking, evaluate the effect of reforms on growth; rather, it evaluates the effect of economic fundamentals on growth. But economic fundamentals may depend on many factors in addition to reforms. Reforms may or may not be successful in moving fundamentals in the desired direction. Hence, it is probably appropriate to interpret the cross-country regression literature as measuring the impact of successful reforms on growth, where success is defined in terms of moving a particular fundamental in a desired direction. On this basis, one would expect that focusing on the effect of reforms per se would produce a rather less tight connection with growth than crosscountry regressions focusing on economic fundamentals that might or might not respond to reforms.

This is confirmed by a small literature (Lora and Barrera, 1997; Escaith and Morley, 2000; Lora and Panizza, 2002), that examines the effects of structural reforms as measured by the Lora (2001) index of trade liberalization, financial sector reforms, tax reforms, privatization, and labor reforms. Unlike the variables that are used to measure economic fundamentals in the cross-country literature, these indices are summary descriptions of policy variables such as average tariffs (for the trade policy index), the cumulative value of companies sold (for the privatization index), reserve requirements, interest rate controls and the adoption of Basel criteria (for the financial policy index), and so on. The most updated of the three studies (Lora and Panizza, 2002) still shows a positive link between reforms and growth. Among the two subindices, trade liberalization and financial sector reform have a reasonably robust positive impact. However, the impact of reforms on growth appears to be temporary (in the sense that the change in the reform index rather than its level matters) except in countries with good institutions (the interaction between reform levels and a rule of law index has a positive and sometimes statistically significant effect). Moreover, the economic impact of reforms on growth was generally smaller than the standard cross-country growth regressions had suggested. On average, structural reforms in Latin America raised the annual GDP growth rate by $0.6-1.3$ percent annually between the late 1980s and late 1990s. The cumulative impact of reforms between 1985 and 1999 was to raise income in the region by about 11 percent. Cumulative increases for countries that underwent significant external openings were higher, however, in the order of 17-27 percent. 
Finally, typical cross-country growth regressions capture average effects, based on a large sample of countries (typically, around 80, of which only about a quarter are in Latin America). They hence embody a number of "homogeneity" and "linearity" assumptions: that reforms work the same way in Latin America as in the rest of the world; that they work the same way in every Latin American country, and that they have the same marginal impact at every level of fundamentals. These assumptions may be justified and indeed necessary as a way of broadly summarizing the information contained in the data. At the same time, however, they are not necessarily a reliable guide for predictions of the effects of reforms in specific countries, because countries may be different, and reforms may interact, in ways that are not captured by the standard empirical models. As pointed out by Dixit (2005), the question that policy advisers should really be interested in is not "What creates success on average across countries?" but "What is going wrong in this country and how can we put it right?” The question is what that might mean in practice, and whether there is a superior alternative to simply taking the results of cross-country growth regressions at face value. We return to this point in Section $\mathrm{C}$ below.

\section{B. "Reforms Have Gone Too Far"}

The market-oriented reforms that were undertaken in Latin America in the late 1980s and early 1990s have a wide spectrum of critics. Extreme critics argue that reforms were altogether a mistake, and that it would have been better to simply continue with the development paradigms of the 1960s and 1970s. More nuanced versions of the criticism state that reforms went too far in specific areas, or had unintended and counterproductive effects.

The radical critics include the political far left in and outside the region, as well as segments of the anti-globalization movement in the North (for example, Weisbrot, 2005; Weisbrot and Rosnick, 2003). In a nutshell, their argument is that the reforms of the 1980s and 1990s were a failure because per capita growth in Latin America in the past 25 years was much lower than in the pre-reform 1960s and 1970s, and that Latin America would be better off today if it had continued the development strategies of the pre-reform period.

This argument is misleading for two reasons. First, it conflates the disastrous experience of the debt crisis period with the post-reform growth record of the 1990s and beyond. Whatever one may think of the latter, the debt crisis and the ensuing period of stagnation during the 1980s cannot be blamed on reforms that in most countries did not start until the end of the decade (the main exception being the successful case of Chile, which both started its reforms earlier and grew very rapidly in the 1980s). Rather, stagnation in the 1980s resulted from the unwinding of excessive debt taken on in the 1970s, as well as from external shocks. Second, the argument exaggerates the achievements of the 1960s and 1970s. Relative to growth in the rest of the world, even the 1960s and 1970s were a period of decline. Moreover, as argued by Fraga (2004), state-led growth based on import-substitution and public investment was both unsustainable in the sense that it resulted in quickly rising levels of public debt (Figure 10), and showed signs of exhaustion by the 1970s, as witnessed by the fact that TFP growth during that decade was approximately zero on average (Figure 4). 
More nuanced versions of the criticism have been argued by a number of governments and political movements in Latin America as well as a several influential academic economists in the United States (Joseph Stiglitz, Dani Rodrik, and recently Jeffrey Sachs in a speech to the OAS). These critics recognize that the 1970s growth paradigm was unsustainable and some degree of reform was inevitable, but argue that reforms overshot, in two ways.

At a philosophical level, the case is made that reforms went too far in taking government out of the economy: moving Latin America all the way from an omnipresent and suffocating state to a minimalist role of government, which leaves the economy rudderless — without a national development strategy or industrial policy — and the poor unprotected. The perceived challenge for the present and future is finding a happy medium between these extremes; an "intelligent state" that draws on the strengths of both approaches (Kirchner, 2003).

At a practical level, reforms are believed to have had some undesirable consequences that ended up negating a large portion, if not all, of the benefits that were originally sought when the reforms were implemented. For example, pension reforms had large fiscal costs; external liberalization and privatization led to declines in manufacturing employment and exposed the economy to higher volatility from abroad; and fiscal consolidation led to a drop in public investment and hence a deterioration of the infrastructure. These problems are held responsible for the mediocre growth performance of the post-reform period, and even more for the deterioration of income distribution in some countries. They could have been avoided, according to the critics, by a more gradual or selective approach to reforms.

What is the evidence in favor or against these arguments? The answer varies, depending on the precise claim. Given the subject of the paper, we focus on growth implications of reforms, though the distributional and social implications of reforms are obviously very important as well, and at least as controversial. ${ }^{15}$

First, there is no doubt that some reforms did in fact have some unintended and undesirable consequences (see World Bank, 2005, for a broad overview, and IMF, 2005, for a case study of Bolivia). However, the suggestion that reforms did more harm than good is not supported by either industry-level or cross-country evidence. In essence, the cross-country evidencewhether based on measures of economic fundamentals or direct measures of reformindicates that while growth in the 1990s was mediocre in most countries of Latin America, it was better in the reforming countries, particularly in countries that liberalized trade and reformed the role of the state in the financial sector. The cross-country evidence on privatization appears to be less clear-cut, though the industry-level evidence is supportive, at least as far as the output and productivity effects of privatization is concerned. ${ }^{16}$ On the

\footnotetext{
${ }^{15}$ On these, the effects of economic liberalization on income distribution in Latin American countries appear to have been mixed (see Vos, Taylor, and Barros, 2002, and country case studies therein). Region-wide poverty has been reduced but by at a slow pace, from 28.4 to 24.5 percent of people living on less than 2 dollars a day, between 1990 and 2001, according to World Bank estimates. Longevity and social indicators have improved significantly, however; see Figure 8 and (in much more detail) Perry and others, 2006.

${ }^{16}$ The flip side of higher productivity is usually employment losses in the privatized firms. However, privatization does not appear to have led to higher overall unemployment (IDB, 2004). In addition, the social
} 
whole, the empirical evidence on growth is inconsistent with calls for protectionism, or for the renationalization of privatized industries.

Second, there are some aspects of the critique on which there simply is insufficient evidence. The case for more gradualism is empirically hard to evaluate, and the two papers that have something to say on this issue in the Latin American context (Escaith and Morley, 2000; and Lora and Panizza, 2002) have inconsistent results. On industrial policy, the failure of stateled industrial development in Latin America in the 1970s (see Fraga, 2004, for an overview) stands in contrast with the experience of East Asia, which is sometimes cited as an example of successful industrial policy. ${ }^{17}$ Clearly, if industrial policy is to have better results in Latin America than in the past, it would need to be approached differently, but the question is how. Some academic economists have recently made suggestions in this area (Hausmann and Rodrik, 2003; Rodrik, 2004c); though their ideas are controversial (see next section).

Third, there is fairly uncontroversial evidence, based on cross-country growth regressions, that improving physical infrastructure—roads, telecommunications, and utilities—helps growth (Loayza, Fajnzylber, and Calderón, 2005; Easterly and Servén, 2003 and references therein). There is also evidence that fiscal consolidation in Latin America in the 1980s and 1990s was in part achieved through cuts in public investment in infrastructure, and that this was only partly made up for by new private investments in infrastructure (Calderón, Easterly, and Servén, 2003; IMF, 2004). Hence, the widening “infrastructure gap” is likely to be one reason why the Latin American output gap relative to East Asia, for example, has been widening (Calderón and Servén, 2003). Of course, the returns from public investments in infrastructure must be compared with the benefits of competing expenditures (for example, in health and education); the costs of higher taxes; and the risks to macroeconomic stability, all of which are also important for growth. However, the basic message from the literature is that the growth risks from compressing public infrastructure spending may be higher than was assumed 15 years ago.

\section{C. "Reforms Have Missed the Point"}

An increasingly popular view argues that reforms failed to stimulate growth in Latin America not because they were too timid, or poorly implemented, or destructive, but simply because they were (mostly) irrelevant. Its popularity seems to have three reasons. First, rather like the original Washington consensus in its day, it is inspired by cutting-edge developments in economic thought. Second, unlike the Washington consensus, it is not easily pigeonholed in terms of the left-right spectrum that has dominated (and continues to dominate) much of the

implications of privatization appear to have been far less egregious than is often assumed, as the higher cost of the formerly public services was usually more than offset by substantially better access (Birdsall and Nellis, 2005).

${ }^{17}$ The claim that East Asia grew fast thanks to industrial policy is itself controversial. In an extensive study of eight East Asian economies, the World Bank (1993) rejected that claim, arguing that growth in East Asia was primarily due to high domestic savings, macroeconomic stability, and market-friendly policies. However, it also found that once these fundamentals are in place, "careful policy interventions to accelerate growth" can be very successful. 
economic policy debate in and on Latin America. Third, at least in some variants, the approach does seem to offer new policy implications, though perhaps less radically so than it seems at first (see below).

The defining theme of this approach is that reforms failed because they did not remove critical growth constraints. Within that broad theme, there are two variants. One is based on the view that there are a small number of causes for economic growth-or the lack of growth-that apply everywhere. Reforms failed because they did not address these causes. Even if the presumed "holy grail" of growth of the late 1980s and early 1990s_market forces - did not fully live up to its promise, there may be a small number of alternative holy grails - overarching causes of high growth, such as good institutions - that can potentially guide a reform program. The second variant amounts to a call to stop searching for a single panacea, and instead focus on removing whatever seems to be the binding constraint in a particular country at a particular point in time. We briefly review both in turn.

\section{Fundamental Constraints to Growth}

In recent years, there has been a rapidly growing economic literature on the "fundamental" causes of long run-growth-causes more fundamental than good policies, in the sense that they explain persistent differences in growth over many centuries, and the enormous difference in per capita incomes across countries. Most successful in recent years, in terms of both high profile publications and influence on policy practitioners, has been the idea that institutions - societal arrangements, both informal and formal, that govern the exercise of political power, set public policy, and define the constraints under which markets operateare the determinant of long-term growth. ${ }^{18}$ With this broad definition, there are of course many channels through which institutions could affect growth. Perhaps three have attracted most attention: first, secure property rights and contract enforcement, widely viewed as the basis of any investment and entrepreneurial activity; second, competition and hence incentives for innovation and productivity growth; and third, quality government services and policies. Another channel that has recently been emphasized, and may be particularly important for Latin America, is the link between institutions and economic volatility, which in turn affects growth. Institutions may affect the capacity of countries to cope with internal and external shocks (Rodrik, 1999; Sahay and Goyal, 2006).

Institutions are not the only "holy grail" that has been proposed in the literature. A competing school has argued that human capital accumulation and education are instead the key to long-run growth (Glaeser and others, 2004). In addition, geography, and income distribution (or more broadly, social cohesion, which may be threatened by ethnic and linguistic divisions as well as economic inequality) have been proposed as fundamental

\footnotetext{
${ }^{18}$ The view that institutions matter has a long history in political science and development economics, and "property rights" was in fact part of Williamson’s (1990) "Washington consensus," though not its main focus. The view became part of the economic mainstream through a series of empirical papers that include Hall and Jones (1999); Acemoglu, Johnson, and Robinson (2001); Easterly and Levine (2003); and Rodrik, Subramanian and Trebbi (2004). See also Acemoglu, Johnson, and Robinson (2005) for a survey and Kaufmann, Mastruzzi, and Zavaleta (2003) for an excellent case study in a Latin American context.
} 
causes of long run growth (Sachs, 2003; Easterly, Ritzen, and Woolcock, 2005). These deep causes might affect growth via institutions (for example, because climate and settler mortality determined the type of institutions set up by European colonial powers, as argued by Acemoglu, Johnson, and Robinson, 2001) but they may also have direct effects. For example, geography may have an impact on public health and transport costs, even with the best institutions (Gallup, Mellinger, and Sachs, 1998, Sachs 2003). And for a given set of institutions, lack of social cohesion may make it easier for conflicts to erupt, for example, as a consequence of external shocks.

Suppose, then, that growth is constrained by any of these fundamental factors - a country has institutions that fail to protect entrepreneurs from the threat of expropriation; or allow incumbent industrialists to erect barriers to entry; or it is landlocked and suffers from prohibitive transport costs; or it is malaria-ridden; or it has long-standing grievances that result in violent distributional conflicts every time the economy performs either better or worse than expected. What will liberalization and stabilization do in this context? In the short run, there may be output gains simply because liberalization and stabilization, even in adverse institutional, geographical, or distributional settings, remove large inefficiencies. But once this has been done, the institutional, geographical, or distributional constraints kick in, and the country stays on a slow growth path. Hence, the "fundamental constraints" view predicts an output pattern, in response to stabilization and liberalization, that is broadly in line with the growth experience of several Latin American countries in the 1990s: a brief period of relatively fast growth, followed by stagnation.

The question is what follows from this diagnosis for the reform agenda. The most obvious answer, and one that began to be embraced by international organizations such as the World Bank, the IMF, and the Inter-American Development Bank since the mid 1990s, is that there needs to be a "second generation of reforms" that addresses the deep constraints to growth more directly (Naím, 1994; see also Singh and others, 2005 for a recent example). For example, reforms must be focused on building an independent and professional judiciary; improving the quality of civil services, creating new fiscal institutions, making central banks independent, and so on. To the extent that income distribution is the problem, reforms could include land reform or tax policy reforms that make the tax system less regressive. Geographical disadvantage might call for specific investments and reforms-for example, in the health sector, or transportation infrastructure - that are geared toward alleviating these disadvantages (Gallup, Gaviria, and Lora, 2005). And lack of human capital obviously calls for special investments in education. Framed in this way, the policy implications of the "fundamental constraints" view are indistinguishable from the call to broaden reforms, discussed in Section A. This explains why the view has been so readily adopted by the original advocates of market reforms. In effect, the confluence of the experience with firstgeneration reforms in Latin America with the academic diagnosis of fundamental growth constraints has given rise to an "augmented Washington consensus".

Recently however, this augmented consensus - particularly in its emphasis on institutional reform-has come under criticism, including from some of the originators of the diagnosis (Rodrik, 2004a, 2006). The criticism runs as follows. 
First, fundamental constraints on long-run growth - particularly in the area of institutionsmay not be easily amenable to reform. Historically, institutions tend to be fairly persistent. The reasons for this include the close interaction between institutions and political or economic interests. Institutional reforms will be heavily resisted where they harm the interest of incumbent elites and interest groups. Even if they superficially achieve their objectivesfor example, by changes in laws or the creation of nominally independent agencies - these objectives could be undermined and reversed. Nominally independent agencies can be captured or corrupted, or, they may face latent constraints due to weak political institutions (Tommasi, 2006, Spiller and Tommasi, 2007). These constraints may quickly become binding in crisis times, through the reversal or failure to enforce specific laws, the forced resignation of heads of "independent" agencies, and so on.

Second, even if institutions could be reformed, we may not know where to begin. The economics literature offers very little guidance in this respect: we know the properties or outcomes of good institutions-for example, that they make investors feel secure-but not necessarily how to achieve these outcomes. Moreover, institutional arrangements that produce similar outcomes may be wildly different depending on other developmental or institutional characteristics of societies. "Institutional function does not uniquely determine institutional form” (Rodrik, 2006). For example, securing property rights may take an independent court system in some countries, but in other countries, where such a court system is lacking and the state is strong, a more effective approach might be to co-opt the state as an entrepreneur (as in the case of Township and Village Enterprises in China).

The economics profession appears to have reacted to these criticisms at several levels. One reaction, articulated by Hausmann, Rodrik, and Velasco (2005), is to reject the idea of a unified reform paradigm altogether, and instead replace it by a framework for diagnosing the principal constraint that might be holding back growth in a specific country at a specific time. We return to this idea in the final section below. Another reaction retains the view that common constraints to growth exist in many developing countries-in particular, weak institutions - and that new, innovative, and perhaps indirect ways must be found to remove these constraints. Within this school of thought, current research appears to be pursuing two main sets of ideas.

The first can be viewed as an attempt to tackle head on the problems described above. In response to the first criticism-that piecemeal institutional reform is often futile-reform efforts may want to focus on political institutions that are of overwhelming importance in determining policy either directly or through the design of economic institutions. Attempts to reform such institutions might be successful if they focus on the basic incentives and rules that determine the "policymaking game" (for example, within the legislature, or with respect to the relationship between various branches of government). By studying the functioning of this policymaking game carefully country by country, it may be possible to draw conclusions on which rules would need to be changed to produce better policymaking outcomes, in the sense that policies become more stable, adaptable, consistent, or command higher public regard. This is the line taken by Spiller, Stein, and Tommasi (2003) and, building on their work, by a number of country-level studies sponsored by the Inter-American Development Bank (IDB, 2006; see Tommasi, 2006, for an overview). The flavor of this literature is that 
constitutional, legal, or process reforms can have real effects on policy outcomes, and in particular, that policy outcomes tend to be better if the rules of the policymaking game encourage cooperative behavior among political actors. However, which reforms are needed in order to achieve this cooperative outcome may vary greatly across countries, depending on the set of policymaking rules already in place.

The second recent idea is to focus on creating constituencies for institutional reform rather than on institutional reforms themselves (Rajan and Zingales, 2006; Rajan, 2006). One way in which such constituencies might be created is through education (Glaeser, Ponzetto, and Shleifer, 2006). Another is through economic growth that benefits reform-minded groups, for example, groups that seek higher political participation, much like the industrial revolution in continental Europe created a bourgeoisie that began pushing for political reforms in the mid$19^{\text {th }}$ century. This puts the focus back on the policies (or "levers" as they are called in this literature) that might trigger a virtuous cycle of growth, institutional reform, and further growth. According to Johnson, Ostry, and Subramanian (2006), for example, it is growth in international trade in manufactured goods that creates pro-reform constituencies. Hence the key to unlocking long-term growth is policies that stimulate manufacturing exports. But what are those policies? High on the list would presumably be a competitive exchange rate, and trade liberalization. The former was item number 5 in the original, 10-point "Washington consensus" list; the latter item number 6 (Williamson, 1990). We seem to be coming full circle now.

\section{Binding Constraints at the Country Level}

The alternative version of the "binding constraints" argument, developed by Hausmann and Velasco (2005), is that Latin America is not growing faster because of a variety of distortions and constraints that may be quite different across countries. The intellectual flaw in approaching the mystery of missing growth in Latin America, in the view of these authors, is in assuming that similar constraints to growth apply everywhere in Latin America. Common outcomes, they argue, do not imply common causes. Similarly, the policy flaw has consisted in directing the same "spray-gun" of Washington-consensus-style reforms at all countries, rather than reforms targeted at removing the constraints that really bind. One would expect this approach to be successful only if the binding constraints to growth just happened to coincide with the reforms that the Washington consensus emphasized. According to Hausmann and Velasco, that was the exception rather than the rule. ${ }^{19}$

\footnotetext{
19 The intellectual foundation of these papers is Lipsey and Lancaster's (1956) "General Theory of the Second Best.” In the presence of many distortions, wholesale reform-removing all distortions at the same time-will take the economy to the first best. Arguably, this is what Washington-consensus reforms, or "big bang” type reform packages in Eastern Europe, were trying to do. However, Hausmann, Rodrik, and Velasco (2005) argue that even the most comprehensive reform package is likely to miss important distortions. If that is the case, the standard prediction of Lipsey and Lancaster's theory applies, which is that piecemeal reform-removing just a single or a few distortions at a time-can be ineffective, or even welfare reducing. For example, removing an external distortion such as controls on capital inflows without addressing distortions in the financial sector can be welfare reducing by contributing to a crisis (as in Chile in 1982 or in emerging Asia in 1997).
} 
The obvious question is how country-specific growth constraints can be identified and removed. To answer this, Hausmann, Rodrik and Velasco (2005) suggest a framework-in essence, a decision tree-for spotting the binding constraint. They start off with an economic principle that is so general as to be consistent with almost any model of economic growth: lack of investment or entrepreneurship must have to do with low returns to these activities relative to the cost of finance. They then develop a taxonomy of possible causes for why the cost of finance could be high or returns to investment or entrepreneurship could be low. Finance could be expensive because of either international or domestic capital market failures. The latter in turn could be related to low domestic savings, or poor financial intermediation. The returns to private investment could be low either because of low social returns — due to poor infrastructure, difficult geography, or low human capital—or because high social returns cannot be appropriated by investors. The latter in turn could be because of government failures - due to macroeconomic risks, high taxes, corruption, or other expropriation risks — or market failures, including information externalities or coordination failures. In effect, Hausmann, Rodrik, and Velasco propose a checklist of what could be wrong with an economy, together with an algorithm for moving through that checklist so that the growth analyst will hopefully end up discovering the binding constraint.

Hausmann, Rodrik, and Velasco have no doubt done policy practitioners a great service both by giving practical suggestions and by bestowing intellectual legitimacy to a commonsensical approach to growth analysis that one would hope has been implicit in much applied policy work on Latin America in the past decade. The question "What is wrong with this country, and how can it be fixed" is of course one that has received regular attention in IMF and World Bank country reports, for example, even if it was not framed in terms of "growth diagnostics" (and notwithstanding the international financial institutions' general support for market-oriented reforms). The question is whether a more systematic application of the growth diagnostics framework could significantly improve policy advice, and eventually translate into targeted reforms that boost growth in the region. There are perhaps three reasons to be somewhat skeptical.

The first potential objection concerns the principle of focusing only on the currently binding constraint. Suppose one manages to successfully identify and remove that constraint. How long will it take for the next constraint to become binding? If the answer is 10 years-as appears to have been the case in the Dominican Republic, whose growth spurt in the 1990s ended with a financial crisis in 2003-then one can imagine an approach to growth policy that simply removes constraints one at a time, as they become binding. If the answer is one or two years, then focusing on the single binding constraint may not be enough. This is what Rodrik (2004b, 2006) seems to have in mind when he suggests that igniting growth - the aim of "growth diagnostics" - may be a different, and indeed easier, matter than sustaining growth. Sustaining growth, in Rodrik's view, requires long-term institutional improvements that make economies resilient to shocks. But that in turn raises the question of how to achieve those improvements, i.e. it puts us back into the dilemmas discussed in the previous sections.

The other objections refer to the practical implementation of the growth-diagnostic decision tree. Most obviously, in a country where many things appear to go wrong, it may not be all 
that obvious which branches of the decision tree the practitioner should pick. To give one example, a World Bank attempt to apply the "growth diagnostics" framework to Bolivia appears to have concluded that Bolivia's low trend growth is a consequence of "lack of national self-discovery" (a residual category of problems that relates to market failures; see Leipziger and Zagha, 2006). In contrast, an excellent country study by Kaufmann, Mastruzzi, and Zavaleta (2003) puts the blame squarely on government failures of various types, while Lora (2001) blames geography and poor infrastructure. In a case like this, it is difficult to avoid the conclusion that what is needed is a long list of reforms and better policiesprecisely the conclusion that Hausmann, Rodrik, and Velasco want to avoid.

Finally, and perhaps most important, growth diagnostics may tell us what the binding constraint is, but very little about how to fix it. The basic problem raised by Rodrik (2004) in his criticism of "institution fundamentalism"-namely, that "institutional function does not determine institutional form," so that conversely institutional dysfunction does not determine any particular reform — cannot be avoided by applying the growth diagnostics framework. If we follow Kaufmann, Mastruzzi, and Zavaleta (2003), for example, and conclude that the binding constraint in Bolivia is the "patronage state," what follows from this? Constitutional reform? Reform of the judiciary? Civil service reform? Creation or reform of particular government agencies? All of the above? And how do any of these reforms stand a chance if there are no constituencies that support them? We are back to the problems of the previous section. The situation seems even more hopeless if we were to have concluded that the real problem is "lack of national self-discovery." How can a process of national self-discovery be instituted that does not fall into the traps of the industrial policy of the 1960s and 1970s?

Ultimately, "growth diagnostics" will have to be evaluated by how well it does in practice. With the help of Hausmann, Rodrik, and Velasco, the World Bank has recently applied growth diagnostics to a group of 12 countries. The results appear to have been mixed, though it is too early to draw firm conclusions (Leipziger and Zagha, 2006).

\section{ConcLusions}

The policy debates triggered by the last round of crises and lagging economic performance in Latin America have not produced a clear "winner," much less a new consensus. In this regard, they differ from the debates of the 1980s, which led to the "Washington consensus," a set of policy prescriptions that was widely supported by policymakers and economists both in the region and outside. This said, based on the facts and literature reviewed in this survey, it is possible to draw a few general conclusions on the most recent debate about growth and reforms in Latin America.

First, while there is no consensus on a new set of policy prescriptions, there are nevertheless several themes in the new debate that seem to command wide support. Most economists and policymakers - including many that continue to believe that stabilization and liberalization were the right policy prescriptions in the 1980s and early 1990s-will now take the view that the "Washington consensus" agenda needs to be either augmented or replaced. Furthermore, there is a widespread view that in order to be successful, reform attempts need to be more mindful of their social and political economy consequences than has been the case in the 
past. It is these consequences that determine whether reforms command broad support or not, and whether they are undermined by special interests. Finally, new prescriptive ideas on reforms have tended to be pragmatic, emphasizing that reforms need to be adapted to country circumstances. For example, the work on "Politics of Policies" sponsored by the InterAmerican Development Bank starts with the premise that weak institutions are a common problem in Latin America, but argues that the solutions might be quite different across countries, depending on the "political game" that is currently in place. In the same vein, Hausmann, Rodrik, and Velasco’s (2005) “growth diagnostics” approach argues that the binding constraints to growth in Latin America might be completely different across countries, and that the key to successful reforms lies in correctly identifying this constraint on a case-by-case basis.

Second, while it is hard to find fault with pragmatism and case-by-case growth analysis, one should not overlook the fact that Latin American countries continue to suffer from a number of common problems that probably inhibit growth in many countries. Latin America has suffered from unusually high macroeconomic volatility. One wonders where the region would stand today if it had either been more resilient to the shocks of the 1990s - in particular, through safer public debt structures, and earlier exits from pegged exchange rate regimes — or had access to better insurance mechanisms to deal with such shocks. Many Latin American countries remain relatively closed, even after the trade liberalization of the past decade. While tariffs have been reduced and quotas have been largely removed, plenty of scope remains for reducing regulatory and bureaucratic barriers to entry-affecting nonresidents and residents alike- - and lowering the cost of doing business in the tradables sector. Finally, Latin America stands out from the rest of the world with its highly unequal income distribution. This has been the source of many problems, particularly when combined with ethnic divisions. Income inequality is associated with higher policy volatility, weaker institutions, and shorter growth spells (Berg, Ostry, and Zettelmeyer, 2006). In addition, poverty may harm growth by creating barriers to human capital accumulation, and excluding large segments of society from financial markets (Perry and others, 2006). Perhaps in recognition of these links, several countries in the region have recently been undertaking social programs — such as the Oportunidades program in Mexico and the Bolsa Familia program in Brazil — that combine income support with education, training, and health measures.

A final observation refers to what we do and do not know about the consequences of economic reforms in particular country circumstances. There appears to be a neglected dimension in the debate that was surveyed: namely, that specific reforms might have been much more successful in some countries than in others. Moreover, the success of some reforms might have been overshadowed or undone by reform or policy failures in other areas. For example, failures in macroeconomic management may have undermined reforms in some countries, even when these reforms were initially delivering high growth, and might have continued to do so in the absence of problems at the macro level. Conversely, the failure of reforms in a specific dimension may have created difficulties for other reforms or macroeconomic management even when they succeeded in other dimensions (the fiscal transition costs of pension reform come to mind, or capital inflows and credit booms triggered by privatizations). 
There may be rich unexplored lessons here, which can probably be learned fully only if the reform experience is disaggregated both by country and reform, while still drawing connections between reforms that were pursued at the same time. Recently, there have been steps in this direction. These include country studies that examine the experience with the international financial institutions' policy prescriptions in the 1990s (including the IMF's $E x$ Post Assessments and studies prepared by the IMF's Independent Evaluation Office), the World Bank's (2005) report on Economic Growth in the 1990s, the Global Development Network's Understanding Reform project (Forteza and Tommasi, 2005), and a new task force report on Helping Reforms Deliver Growth in Latin America prepared under the auspices of the Center for Global Development (Rojas-Suarez and Johnson, 2006). Country and reform-level analysis along these lines will hopefully give us a better sense of how to carry forward reforms in Latin America in years to come. 


\section{REFERENCES}

Acemoglu, Daron, Simon Johnson, and James A. Robinson, 2005, "Institutions as a Fundamental Cause of Long-Run Growth," in Handbook of Economic Growth, Vol. $1 A$, ed. by Philippe Aghion and Steven N. Durlauf (Amsterdam: Elsevier).

__, 2001, "The Colonial Origins of Comparative Development," American Economic Review, Vol. 91/5, pp. 1369-1401.

Adrogué, Ricardo, Martin Cerisola, and Gaston Gelos, 2006, “Brazil’s Long-Term Growth Performance: Trying to Explain the Puzzle” (unpublished; Washington: International Monetary Fund).

Aiolfo, Marco, Luis Catão, and Allan Timmermann, 2006, "Common Factors in Latin America’s Business Cycles,” IMF Working Paper 06/49 (Washington: International Monetary Fund).

Becker, Torbjörn, and Paolo Mauro, 2006, “Output Drops, and the Shocks that Matter” (unpublished; Washington: International Monetary Fund).

Berg, Andy, Jonathan Ostry, and Jeromin Zettelmeyer, 2006, "What Makes Growth Sustained?” (unpublished; Washington: International Monetary Fund).

Benelli, Roberto, 2006, "Debt and Growth in Latin America” (unpublished; Washington: International Monetary Fund).

Birdsall, Nancy, and Augusto de la Torre (with Rachel Menezes), 2001, Washington Contentious: Economic Policies for Social Equity in Latin America (Washington: Carnegie Endowment for International Peace and Inter-American Dialogue).

Birdsall, Nancy, and John Nellis, 2005, "Reality Check: The Distributional Impact of Privatization in Developing Countries" (Washington: Center for Global Development).

Blyde, Juan S., and Eduardo Fernandez-Arias, 2004, "Why Does Latin America Grow More Slowly?” Economic and Social Study Series, RE1-04-016 (Washington: InterAmerican Development Bank).

Bruno, Michael, and William Easterly, 1998, "Inflation Crises and Long-Run Growth," Journal of Monetary Economics, Vol. 41 (February), pp. 3-26.

Calderon, César, and Luis Servén, 2003, “The Output Cost of Latin America’s Infrastructure Gap,” in The Limits of Stabilization: Infrastructure, Public Deficits, and Growth in Latin America, ed. William Easterly and Luis Severn (Washington: The World Bank), pp. 95-118.

Calderon, César, William Easterly, and Luis Servén, 2003, "Infrastructure Compression and Public Sector Solvency in Latin America," in The Limits of Stabilization: Infrastructure, Public Deficits, and Growth in Latin America, ed. by William Easterly and Luis Servén (Washington D.C.: The World Bank), pp. 119-138.

Carstens, Agustin, and Luis Ignacio Jácome, 2005, "Latin American Central Bank Reform: Progress and Challenges,” IMF Working Paper No. 05/114 (Washington: International Monetary Fund). 
Center for Global Development, 2006, Report of the Task Force on Helping Reforms Deliver Growth in Latin America (co-chaired by Simon Johnson and Liliana Rojas-Suarez), forthcoming.

Cohen, Daniel, 1997, “Growth and External Debt: A New Perspective on the African and Latin American Tragedies,” CEPR Discussion Paper No. 1753 (London: Centre for Economic Policy Research).

Cole, Harold, Lee E. Ohanian, Alvaro Riascos, and James A. Schmitz Jr., 2005, “Latin America in the Rearview Mirror,” Journal of Monetary Economics, No. 52, pp. 69107.

Cordella, Tito, Luca Antonio Ricci, and Marta Ruiz-Arranz, 2005, “Debt Overhang or Debt Irrelevance? Revisiting the Debt-Growth Link,” IMF Working Paper 05/223 (Washington: International Monetary Fund).

De Carvalho Filho, Irineu, and Marcos Chamon, 2006, “The Myth of Post-Reform Income Stagnation in Brazil” (unpublished; Washington: International Monetary Fund).

De Gregorio, José, and Jong-Wha Lee, 2003, “Growth and Adjustment in East Asia and Latin America,” Working Papers No. 245 (Santiago: Central Bank of Chile).

De Ferranti, David, Guillermo E. Perry, Indermit Gill, J. Luis Guasch, William F. Maloney, Carolina Sánchez-Páramo, and Norbert Schady, Closing the Gap in Education and Technology (Washington: The World Bank).

Dixit, Avinash, 2005, “Evaluating Recipes For Development Success” (unpublished; Princeton: Princeton University).

Djankov, Simeon, Rafael La Porta, Florencio Lopez-De-Silanes, and Andrei Shleifer, 2002, “The Regulation of Entry,” Quarterly Journal of Economics, Vol. 117, No. 1, pp. 137.

Easterly William, 2005, “National Policies And Economic Growth: A Reappraisal,” in Handbook of Economic Growth, Vol. 1A, ed. by Philippe Aghion and Steven N. Durlauf (Amsterdam and London: Elsevier).

—_ Jozef Ritzen, and Michael Woolcock, 2005, "Social Cohesion, Institutions, and Growth” (unpublished; Washington: The World Bank).

Easterly, William, Norman Loayza, and Peter Montiel, 1997, “Has Latin America’s PostReform Growth Been Disappointing?” Journal of International Economics, No. 43, pp. 287-311.

Easterly, William, and Sergio Rebelo, 1993a, "Fiscal Policy and Growth: An Empirical Investigation,” Journal of Monetary Economics, Vol. 32, pp. 417-458.

Easterly, William, and Sergio Rebelo, 1993b, “Marginal Income Tax Rates and Economic Growth in Developing Countries,” European Economic Review, Vol. 37, pp. 409-417.

Easterly, William, and Luis Servén, 2003, The Limits of Stabilization: Infrastructure, Public Deficits, and Growth in Latin America (Washington: The World Bank). 
Easterly, William, and Ross Levine, 2003, "Tropics, Germs, and Crops: The Role of Endowments in Economic Development,” Journal of Monetary Economics, Vol. 50, No. 1, pp. 3-39.

Escaith, Hubert, and Samuel Morley, 2000, “The Impact of Structural Reforms on Growth in Latin America and the Caribbean: An Empirical Estimation,” Macroeconomicas del Desarrollo Series (Santiago, Chile: Economic Commission for Latin America).

Fernandez-Arias, Eduardo, and Peter Montiel, 2001, "Reform and Growth in Latin America: All Pain, No Gain?” IMF Staff Papers, Vol. 48, No.3, pp. 522-545.

Fischer, Stanley, 1993, “The Role of Macroeconomic Factors in Growth,” Journal of Monetary Economics, Vol. 32, No.3, pp. 485-512.

Forteza, Alvaro, and Mariano Tommasi, 2005, "Understanding Reform In Latin America” (unpublished; Montevideo: University of Uruguay).

Fraga, Arminio, 2004, “Latin America Since the 1990s: Rising from the Sickbed?” Journal of Economic Perspectives, Vol., 16, No. 2, pp. 89-106.

Frankel, Jeffrey A., and Andrew Rose, 1996, "Currency Crashes in Emerging Markets: An Empirical Treatment,” Journal of International Economics, Vol. 41, pp.351-66.

Gallup, John Luke, Andrew D. Mellinger, and Jeffrey D. Sachs, 1998, "Geography and Economic Development," in Annual World Bank Conference on Development Economics (Washington: The World Bank).

Gallup, John Luke, Alejandro Gaviria, and Eduardo Lora, 2003, Is Geography Destiny? Lessons from Latin America (Washington: Inter-American Development Bank).

Ghosh, Atish R., and Steven Phillips, 1998, "Warning: Inflation Can be Harmful to Your Growth,” IMF Staff Papers, International Monetary Fund, Vol. 45, No. 4, pp. 672710.

Glaeser, Edward L., Rafael La Porta, Florencio Lopez-de-Silanes, and Andrei Shleifer, 2004, "Do Institutions Cause Growth?” Journal of Economic Growth, Vol. 9, No. 3, pp. 271-303.

Glaeser, Edward L., Giacomo Ponzetto, and Andrei Shleifer, 2006, "Why Does Democracy Need Education?” (unpublished; Cambridge, Mass: Harvard University).

Hall, Robert E., and Charles Jones, 1999, "Why Do Some Countries Produce So Much More Output Per Worker than Others?” Quarterly Journal of Economics, Vol. 114, No. 1, pp. 83-116.

Hausmann, Ricardo, and Dani Rodrik, 2003, “Discovering El Salvador’s Production Potential" (unpublished; Cambridge, Mass: Harvard University).

—_, and Andrés Velasco, 2005, “Growth Diagnostics” (unpublished; Cambridge, Mass: Harvard University).

Hausmann, Ricardo, and Andrés Velasco, 2005, "Slow Growth in Latin America: Common Outcomes, Common Causes?” (unpublished; Cambridge, Mass: Harvard University). 
International Monetary Fund, 2004, “Public Investment and Fiscal Policy,” prepared by the Fiscal Affairs and the Policy Development and Review Department, March 12 (available at http://www.imf.org/external/np/fad/2004/pifp/eng/pifp.pdf).

_ _ 2005, “Bolivia: Ex Post Assessment of Longer-Term Program Engagement,” Country Report No. 05/139.

Inter-American Development Bank, 2006, The Politics of Policies. Economic and Social Progress in Latin America, 2006 Report (Washington: Inter-American Development Bank).

Jaimovich, Dany, and Ugo Panizza, 2006, "Public Debt around the World: A New Dataset of Central Government Debt,” IADB Working Paper No. 661 (Washington: InterAmerican Development Bank).

Jeanne, Olivier, and Anastasia Guscina, 2006, "Government Debt in Emerging Market Countries: A New Data Set,” IMF Working Paper 06/98 (Washington: International Monetary Fund).

Johnson, Simon, Jonathan D. Ostry, and Arvind Subramanian, 2006, “Levers for Growth,” Finance and Development, Vol. 43, No.1, pp. 28-30.

Kaufmann, Daniel, Massimo Mastruzzi, and Diego Zavaleta, 2003, “Sustained Macroeconomic Reforms, Tepid Growth: A Governance Puzzle in Bolivia?” in In Search of Prosperity: Analytic Narratives on Economic Growth, ed. by Dani Rodrik (Princeton: Princeton University Press), pp. 334-398.

Kirchner, Néstor, 2003, “Discurso Del Señor Presidente De La Nación, Doctor Néstor Kirchner, Ante La Honorable Asamblea Legislativa,” speech, May 25 (available on the internet at http://www.presidencia.gov.ar/).

Krueger, Anne O, 2004, “Meant Well, Tried Little, Failed Much: Policy Reforms in Emerging Market Economies,” speech delivered at New York University, March 23 (Washington: International Monetary Fund).

Leipziger, Danny, and Roberto Zagha, 2006, “Getting out of the Rut,” Finance and Development Vol. 43 (March), pp. 16-17.

Lindauer, David L., and Lant Pritchett, 2002, "What's the Big Idea? The Third Generation of Policies for Economic Growth,” Economía, Vol. 3, No. 1 (Fall), pp. 1-28.

Lipsey, Richard G., and Kelvin Lancaster, 1956, “The General Theory of Second Best,” Review of Economic Studies, Vol. 24, pp. 11-32.

Lora, Eduardo, 2001, "Structural Reforms in Latin America: What Has Been Reformed and How to Measure it,” IADB Working Paper No. 466 (Washington: Inter-American Development Bank).

Lora, Eduardo, and Felipe Barrera, 1997, “Una Década de Reformas: El Crecimiento, la Productividad y la Inversión ya no son los de Antes,” paper presented at the Annual Meetings of the Inter-American Development Bank, Barcelona (Washington: InterAmerican Development Bank). 
Lora, Eduardo, and Ugo Panizza, 2002, "Structural Reforms in Latin America under Scrutiny,” IADB Working Paper No. 470 (Washington: Inter-American Development Bank).

Loayza, Norman, Pablo Fajnzylber, and Cesar Calderón, 2005, Economic Growth in Latin America and the Caribbean: Stylized Facts, Explanations, and Forecasts (Washington: The World Bank).

Pattillo, Cathy, Hélène Poison, and Lucca A. Ricci, 2002, "External Debt and Growth,” IMF Working Paper 02/69 (Washington: International Monetary Fund).

Perry, Guillermo E., Omar S. Arias, J. Umberto Lopez, William F. Maloney and Luis Servén, 2006, Poverty Reduction and Growth: Virtuous and Vicious Cycles (Washington: The World Bank).

Pritchett, Lant, 1996, “Measuring Outward Orientation in Laces: Can It Be Done?,” Journal of Development Economics Vol. 49, No. 2 (May), pp. 307-35.

Rajan, Raghuram, 2006, "Crabs in a Bucket: Why Constituencies Are as Important as Constitutions in Battling Underdevelopment," Finance and Development, Vol. 3, No. 2, (June).

— - and Luigi Zingales, 2006, “The Persistence of Underdevelopment: Institutions, Human Capital, or Constituencies?” NBER Working Paper No. 12093 (Cambridge, Mass.: National Bureau of Economic Research).

Rodrik, Dani, 2004a, “Getting Institutions Right” (unpublished; Cambridge, Mass: Harvard University).

— , 2004b, “Growth Strategies” (unpublished; Cambridge, Mass: Harvard University).

—_, 2004c, "Industrial Policy for the Twenty-First Century" (unpublished; Cambridge, Mass: Harvard University).

—_, 2006, “Goodbye Washington Consensus, Hello Washington Confusion?” (unpublished; Cambridge, Mass: Harvard University).

—_, Arvind Subramanian and Francesco Trebbia, 2004, "Institutions Rule: The Primacy of Institutions over Geography and Integration in Economic Development,” Journal of Economic Growth, Vol. 9, No.2 (June), pp. 131-65.

Rojas-Suarez, Liliana, and Simon Johnson, 2006, "Helping Reforms Deliver Growth in Latin America” (unpublished report; Washington: Center for Global Development).

Sachs, Jeffrey D., 2003, “Institutions Don’t Rule: Direct Effects of Geography on Per Capita Income,” NBER Working Paper No. 9490 (Cambridge, Mass: National Bureau of Economic Research).

Sahay, Ratna, and Rishi Goyal, 2006, "Volatility and Growth in Latin America: An Episodic Approach” (unpublished; Washington: International Monetary Fund).

Singh, Anoop, 2006, "Macroeconomic Volatility: The Policy Lessons From Latin America," IMF Working Paper 06/166 (Washington: International Monetary Fund). 
— Perspective on the Experience Since the Early 1990s,” Occasional Paper 238 (Washington: International Monetary Fund).

Spiller, Pablo, Ernesto Stein, and Mariano Tommasi, 2003, "Political Institutions, Policymaking Processes, and Policy Outcomes: An Intertemporal Transactions Framework” (unpublished; Washington: Inter-American Development Bank).

Spiller, Pablo, and Mariano Tommasi, 2007, The Institutional Foundations of Public Policy in Argentina. A Transactions Cost Approach, forthcoming (Cambridge: Cambridge University Press).

Sturzenegger, Federico, and Jeromin Zettelmeyer, 2006, Debt Defaults and Lessons from a Decade of Crises, forthcoming (Cambridge, Mass. and London: MIT Press).

Tommasi, Mariano, 2006, “The Institutional Foundations of Public Policy,” Presidential Address to the Latin American and Caribbean Economic Association (LACEA), forthcoming in Economía, Vol. 6, No. 2.

Weisbrot, Mark, 2005, “Latin America’s Long Economic Failure Sparks Desire for Change,” (Washington: Center for Economic and Policy Research).

—_ and David Rosnick, 2003, “Another Lost Decade? Latin America’s Growth Failure Continues Into the $21^{\text {st }}$ Century,” (Washington: Center for Economic and Policy Research).

World Bank, 2005, Economic Growth in the 1990s: Learning from a Decade of Reform (Washington: The World Bank).

Vos, Rob, Lance Taylor, and Ricardo Paes de Barros, 2002, Economic Liberalization, distribution, and poverty: Latin America in the 1990s (Northampton: Edward Elgar). 